\title{
Intermolecular Diels-Alder Cycloaddition for the Construction of Bicyclo[2.2.2]diazaoctane Structures: Formal Synthesis of Brevianamide B and Premalbrancheamide
}

Jacob G. Robins

College of William \& Mary, Dept Chem, POB 8795, Williamsburg, VA 23187 USA

Kyu J. Kim

College of William \& Mary, Dept Chem, POB 8795, Williamsburg, VA 23187 USA

Alex J. Chinn

College of William \& Mary, Dept Chem, POB 8795, Williamsburg, VA 23187 USA

John S. Woo

College of William \& Mary, Dept Chem, POB 8795, Williamsburg, VA 23187 USA

Jonathan R. Scheerer

College of William \& Mary, Dept Chem, POB 8795, Williamsburg, VA 23187 USA

Follow this and additional works at: https://scholarworks.wm.edu/aspubs

\section{Recommended Citation}

Robins, J. G., Kim, K. J., Chinn, A. J., Woo, J. S., \& Scheerer, J. R. (2016). Intermolecular Diels-Alder Cycloaddition for the Construction of Bicyclo [2.2. 2] diazaoctane Structures: Formal Synthesis of Brevianamide B and Premalbrancheamide. The Journal of organic chemistry, 81(6), 2293-2301.

This Article is brought to you for free and open access by the Arts and Sciences at W\&M ScholarWorks. It has been accepted for inclusion in Arts \& Sciences Articles by an authorized administrator of W\&M ScholarWorks. For more information, please contact scholarworks@wm.edu. 


\title{
Intermolecular Diels-Alder Cycloaddition for the Construction of Bicyclo[2.2.2]diazaoctane Structures: Formal Synthesis of Brevianamide B and Premalbrancheamide
}

\author{
Jacob G. Robins, Kyu J. Kim, Alex J. Chinn, John S. Woo, and Jonathan R. Scheerer* \\ Department of Chemistry, The College of William \& Mary, P.O. Box 8795, Williamsburg, Virginia 23187, United States
}

Supporting Information

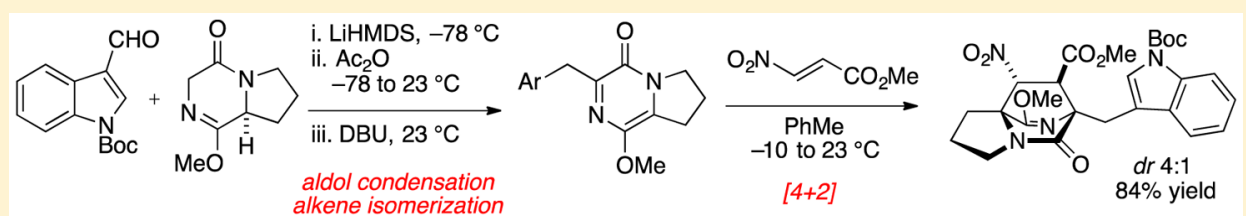

ABSTRACT: A stereoselective intermolecular Diels-Alder cycloaddition of an intermediate pyrazinone with both achiral and chiral acrylate-derived dienophiles provides rapid access to the bicyclo[2.2.2] diazaoctane core shared among several prenylated indole alkaloids. The product derived from cycloaddition with 2-nitroacrylate required an additional five to six synthetic operations to intercept established precursors to premalbrancheamide and brevianamide $\mathrm{B}$. The chemistry detailed in this manuscript constitutes a formal total synthesis (12 steps each) of these [2.2.2] diazabicyclic natural products from proline methyl ester.

\section{INTRODUCTION}

Isolated by Birch and Wright in 1969, the brevianamides were the first metabolites discovered that possess the bicyclo[2.2.2]diazaoctane architecture. ${ }^{1}$ The [2.2.2] diazabicyclic alkaloid family has since grown and now numbers nearly 100 distinct fungal-derived prenylated indole natural products. ${ }^{2}$ Intriguing biological activity is found across the family, and the alkaloids exhibit antitumor, antihelmintic, insecticidal, and selective phosphodiesterase (PDE1) inhibition and neuroprotective properties. $^{2,3}$ As a result, the [2.2.2] diazabicyclic alkaloids are lead compounds in the treatment of several diseases and cancer.

Within the [2.2.2] diazabicyclic alkaloid family, metabolites can possess either the syn or anti stereochemical configuration at C19 (brevianamide numbering). ${ }^{4}$ Continued isolation efforts have revealed enantiomeric ${ }^{5}$ and epimeric ${ }^{6}$ metabolites from different fungal organisms (e.g., (+)-, (-)-stephacidin A, and 6epi-stephacidin A, Figure 1), a discovery that only increases the allure of these alkaloids.

Because of potent and diverse bioactivities as well as appealing molecular structure, the entire alkaloid group has attracted the attention of the synthetic community. Efforts directed to the synthesis of various congeners have revealed several methods for the construction of the [2.2.2] diazabicyclic core: (1) $\mathrm{S}_{\mathrm{N}} 2^{\prime}$ cyclization, (2) biomimetic intramolecular Diels-Alder cycloaddition (IMDA), (3) $\mathrm{N}$-acyliminiuminitiated cyclization, (4) oxidative enolate coupling, (5) radical cyclization, and (6) Dieckmann condensation with an isocyanate component. ${ }^{7,8}$

The epimeric [2.2.2] diazabicycles $\mathbf{1}$ and $\mathbf{2}$ are the most simple structures that contain all rings apparent within these natural products. The syn-configured 1 can be converted to premalbrancheamide, the biogenic precursor to more highly halogenated compounds (e.g., malbrancheamide A and B). ${ }^{9}$ The anti-configured $\mathbf{2}$ is not a natural product but has served as the penultimate intermediate in several syntheses of brevianamide B (3). ${ }^{10,8 a}$ The synthesis of compounds $\mathbf{1}$ or $\mathbf{2}$ have been a proving ground for methods to construct the [2.2.2]diazabicyclic ring system, and the chemistry revealed in these studies is often applied to more elaborate targets within the natural product family.

The development of the biomimetic IMDA cycloaddition by Williams has resulted in the total synthesis of several [2.2.2] diazabicyclic alkaloids and led to important insights into the biogenesis of these alkaloids. ${ }^{11}$ As an example of this chemistry, diketopiperazine 4 can be isomerized to the reactive pyrazinone intermediate 7 , which undergoes cycloaddition to give the diastereomers 5 and $6(\mathrm{dr} 2: 1$, Figure 2, entry 1$)$. Because the pyrazinone Diels-Alder precursor 7 is achiral, the observed cycloadducts are racemic. Production of asymmetric [2.2.2] diazabicyclic alkaloids via the IMDA has been realized using a chiral aminal auxiliary precursor $8^{8 \mathrm{~d}}$ (e.g., entry 3 ) as well as two other nonracemic substrates. ${ }^{11 \mathrm{a}, 12}$ Additionally, Johnston and co-workers recently extended the IMDA chemistry using a hydrogen bonding catalyst to modulate the diastereo- and enantioselectivity of the reaction (entry 2). ${ }^{13}$ In this way, syn-fused 5 can be produced in up to $4: 1 \mathrm{dr}$ and up to $44 \%$ ee depending on the catalyst used. In many ways, this represents a normal evolution of reaction development, where an initial reaction is rendered diastereoselective first with auxiliaries and later made to be a catalytic enantioselective process.

Received: December 2, 2015

Published: February 26, 2016 


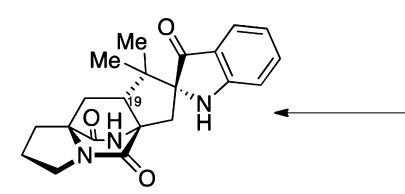

(+)-brevianamide B (3)

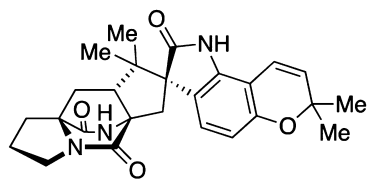

(+)-versicolamide B

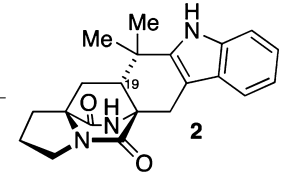

C19 proton anti to $2^{\circ}$ lactam bridge

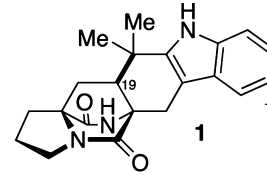

bridge proton syn to $2^{\circ}$ lactam bridge

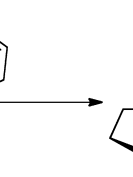

Nin

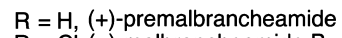
$\mathrm{R}=\mathrm{Cl}(+)$-malbrancheamide $\mathrm{B}$

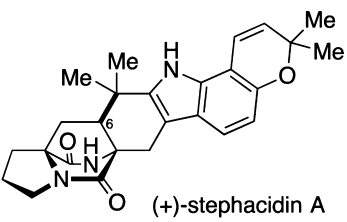

(+)-stephacidin A
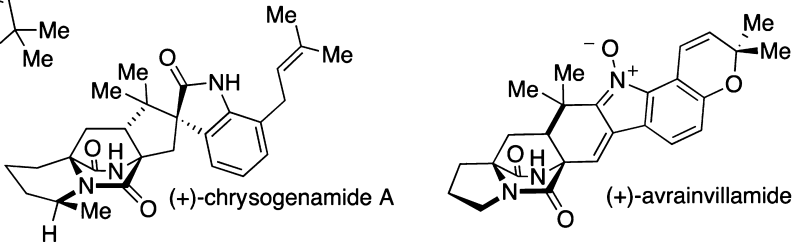

Figure 1. [2.2.2]Diazabicyclic natural products with syn and anti fusion.

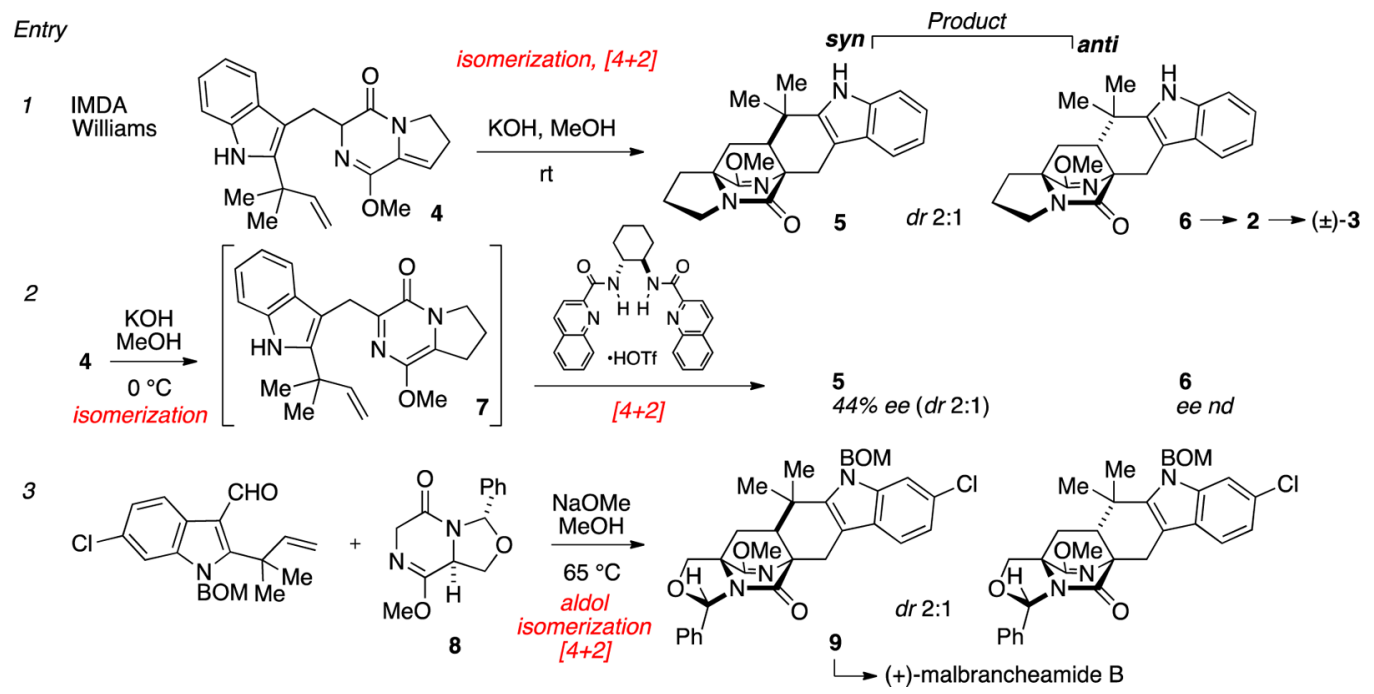

Figure 2. Intramolecular Diels-Alder approaches to the formation of [2.2.2] diazabicyclic structures.

\section{RESULTS AND DISCUSSION}

This manuscript describes our efforts toward $\mathbf{1}$ and $\mathbf{2}$ that focus on an intermolecular Diels-Alder cycloaddition for the construction of the [2.2.2] diazabicyclic system.

The Diels-Alder reaction is naturally efficient (forming two bonds in concerted fashion), and the intermolecular variant is intrinsically convergent. We believed that a strategy based on intermolecular cycloaddition might offer improvements in efficiency over several known routes and potentially permit selective formation of either diastereomer 1 or $\mathbf{2}$ based on modulation of the reaction conditions. Most importantly, the fundamentals of the pyrazinone intermolecular Diels-Alder cycloaddition are not fully understood, and we viewed a synthesis of $\mathbf{1}$ and $\mathbf{2}$ as an instructive target to advance this chemistry in more detail.

We previously established that pyrazinone Diels-Alder precursors can be prepared in a single step by a domino aldol condensation/alkene isomerization sequence. ${ }^{14}$ Accordingly, our proposed synthesis toward $\mathbf{1}$ and $\mathbf{2}$ planned to engage the requisite pyrazinone $\mathbf{1 0}$ prepared in this manner with a suitable acrylate-derived dienophile to afford cycloadduct 3 (Scheme 1). Subsequent addition of an organometallic reagent (e.g., $\mathrm{MeMgBr}$ ) to the ester to afford an intermediate tertiary alcohol would then permit Friedel-Crafts cyclization to produce the quaternary carbon and complete the ring system.
Scheme 1. Retrosynthesis Featuring an Intermolecular $[4+$ 2] Reaction

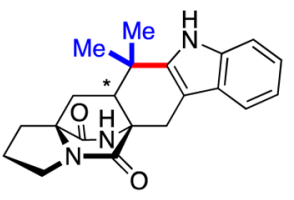

syn-1 or anti-2
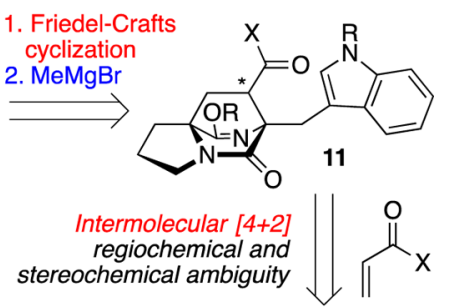

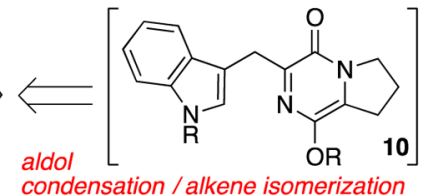

Because both $\mathbf{1}$ and $\mathbf{2}$ are known, we anticipated that verification of stereochemical outcome from the intermolecular cycloaddition could be quickly determined by comparing to published spectroscopic data or authentic standards.

Although this synthesis plan appeared concise, there were significant regiochemical and stereochemical ambiguities with regard to the intermolecular cycloaddition as well as fundamental questions regarding reactivity. We predicted that 
Scheme 2. Intermolecular Diels-Alder Cycloaddition with Acrylate Dienophiles

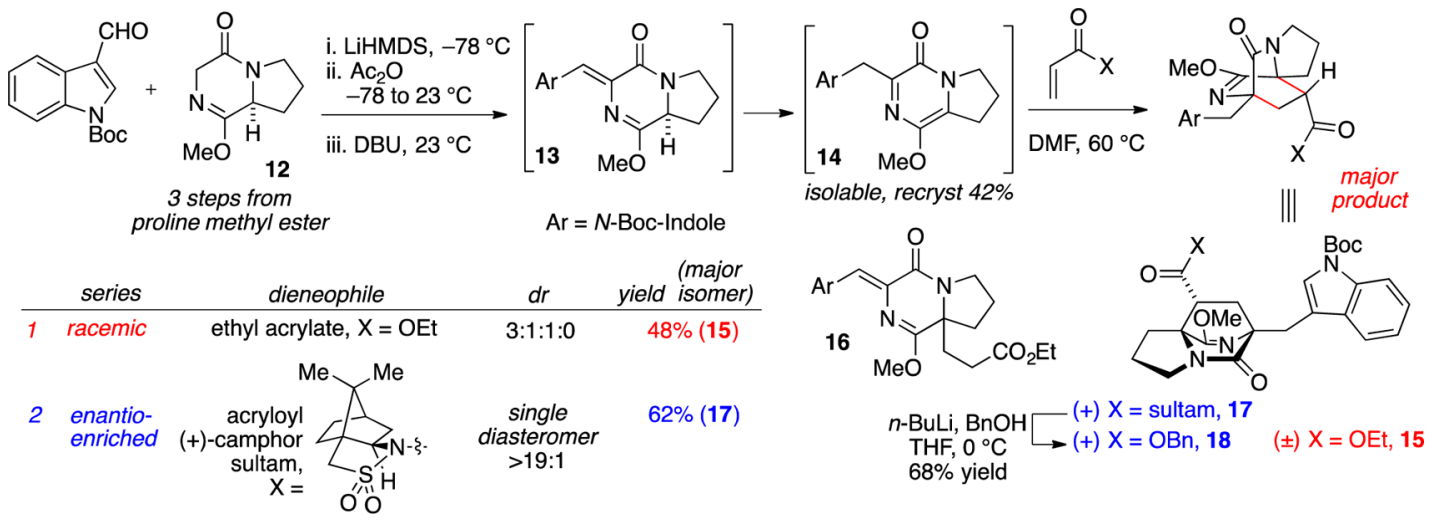

Scheme 3. Cycloaddition with Nitroacrylate and Formal Synthesis of Brevianamide B and Premalbrancheamide

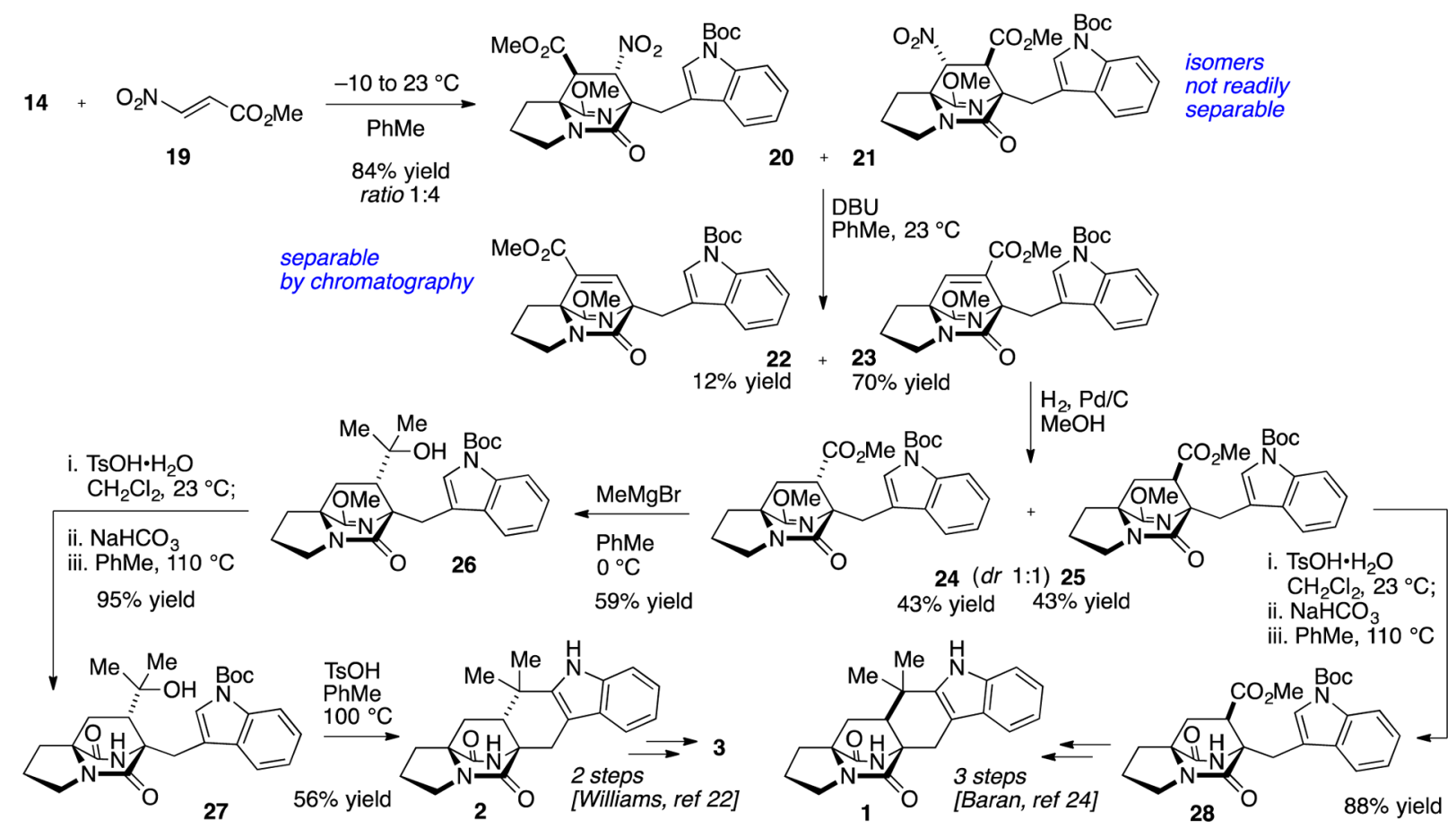

a modest preference for the endo cycloadduct might be enforced (leading to the anti-bicyclo fusion).

In order to evaluate the intermolecular cycloaddition, pyrazinone 14 was prepared in one reaction vessel starting from the proline-derived diketopiperazine (DKP) $\mathbf{1 2}$ (Scheme 2). ${ }^{15}$ The reaction sequence is initiated by enolization (LiHMDS, 1.1 equiv) followed by aldol addition to the indole carboxaldehyde. The intermediate $\beta$-alkoxy adduct was acylated $\left(\mathrm{Ac}_{2} \mathrm{O}, 1.1\right.$ equiv) and treated with base (DBU, 1.4 equiv) in order to effect elimination to the exocyclic diene in 13 and subsequent isomerization to the DKP azadiene 14. Based on experimental evidence, the exocyclic diene in $\mathbf{1 3}$ is short-lived and isomerizes rapidly to the endocyclic azadiene 14, the apparent thermodynamic alkene isomer and only identified product from the reaction.

Although isolable, azadiene $\mathbf{1 4}$ proved somewhat difficult to manipulate. The pyrazinone decomposed on exposure to silica gel and was reactive with air, undergoing decomposition within hours at room temperature. ${ }^{16}$ Nonetheless, we became experienced at handling $\mathbf{1 4}$ as the unpurified product mixture (obtained in 94\% yield from the $\beta$-acetoxyaldol adduct, 90$95 \%$ pure by ${ }^{1} \mathrm{H}$ NMR) or as a homogeneous material obtained by recrystallization, albeit in diminished yield (42\%). In practice, we also found it convenient to isolate and purify the intermediate $\beta$-acetoxy adduct and advance material through the elimination and isomerization to form 14 as needed.

We first attempted Diels-Alder cycloaddition of 14 with ethyl acrylate and observed three products in a 3:1:1 ratio. ${ }^{17}$ The major product 15 was obtained in $48 \%$ isolated yield and corresponds to cycloaddition from the endo transition state. Due to the inconvenience of handling metastable pyrazinone 14, we also attempted a "one pot" reaction in order to circumvent isolation of the reactive intermediate. Addition of ethyl acrylate to the reaction vessel following completion of the aldol condensation and alkene isomerization sequence produced a low yield (15\%) of desired cycloadduct 15 . The observed major product 16 (50\% yield) was the result of Michael addition. Formation of the Michael adduct could be almost completely avoided with addition of a stoichiometric amount of acetic acid (in order to buffer the basicity of residual 
$\mathrm{DBU})$ prior to addition of acrylate. In this way, the desired major cycloadduct $\mathbf{1 5}$ was obtained in a commensurate amount (40\% isolated yield) and identical stereoselection (3:1:1) as compared to the two-step sequence. Overall, this intermolecular Diels-Alder reaction sequence required five to six steps from commercially available proline methyl ester to create the [2.2.2] diazabicyclic structure; however, the dominant product possessed the undesired regiochemistry and would not permit synthesis of $\mathbf{2}$ in a straightforward manner.

In the course of preparing suitable acrylate precursors, we observed that the acrylamide derivative of Oppolzer's sultam was more selective in engaging pyrazinone substrate 14 and could effectively introduce asymmetry to and improve diastereoselection in the cycloaddition. ${ }^{18}$ The thermal cycloaddition of 14 with acryloyl camphor sultam afforded cycloadduct 17 in $62 \%$ yield as an apparent single diastereomer (>19:1) as determined by ${ }^{1} \mathrm{H}$ NMR on the unpurified reaction product mixture (Scheme 2, blue highlight). ${ }^{19}$ The acyl sultam in 17 could be converted with lithio benzyl alcohol into the corresponding ester $1 \mathbf{1 8}^{20}$

In order to obtain the desired regiochemistry whereby the carboxyl moiety is positioned proximal to the indole nucleus, we attempted cycloaddition with methyl 2-nitroacrylate (19), a dienophile substrate that can be effective in reversing cycloaddition regioselectivity. ${ }^{21}$ In the event, nitroacrylate 19 was more reactive than ethyl acrylate and cycloaddition with pyrazinone 14 was achieved near ambient temperatures. Two regioisomeric cycloadducts 20 and 21 (ratio 1:4) were produced in $84 \%$ combined yield (Scheme 3). Both cycloadducts arise from orientation of the nitro function in the endo transition state. The dominant cycloadduct 21 possessed the desired regiochemistry and we turned our attention to the three remaining tasks to assemble the complete ring system relevant to the [2.2.2] diazabicyclic alkaloid family: (1) removal of the nitro group, (2) methylation of the ester (MeMgBr), and (3) Friedel-Crafts cyclization.

Direct radical reduction of the secondary nitro group in $\mathbf{2 1}$ was attempted $\left(\mathrm{Bu}_{3} \mathrm{SnH}, \mathrm{AIBN}, \mathrm{PhMe}, 110{ }^{\circ} \mathrm{C}\right)$, although only the product resulting from elimination (23) was observed. Performing the reduction at lower temperatures $\left(70-80{ }^{\circ} \mathrm{C}\right)$ afforded mostly elimination product 23 but also a limited quantity (ca. $10 \%$ yield) of 25 , thereby validating the stereochemistry of the cycloaddition. Due to the strong propensity for elimination, we found it operationally most convenient to expose the 1:4 mixture of cycloadducts 20 and 21 to DBU, which promoted elimination to the two isomeric unsaturated ester products. The major isomer $\mathbf{2 3}$ was easily separated by chromatography from the regioisomeric product 22. Hydrogenation of the unsaturation in $\mathbf{2 3}$ gave a nearly equal mixture of syn- and anti-fused products 24 and 25 .

Both diastereomers $\mathbf{2 4}$ and $\mathbf{2 5}$ were advanced in a short number of operations to intercept known compounds. Product 24 was converted to anti-fused 2, a well-established intermediate toward brevianamide B. ${ }^{22}$ Toward this end, the ester in $\mathbf{2 4}$ was consumed with excess $\mathrm{MeMgBr}$ to afford the derived tertiary alcohol. Acidic hydrolysis ${ }^{23}$ of the lactim ether functionality to give the lactam 26 was required prior to Friedel-Crafts cyclization of the indole on the derived tertiary carbocation. Intermediate 27 , which features the tertiary alcohol and lactam structures, cleanly underwent indole BOC deprotection and cyclization to give the desired annulated product $\mathbf{2}$ in $83 \%$ yield. The spectral data for product $\mathbf{2}$ thus obtained was identical to all properties of an authentic sample provided by Williams.

The analogous lactim hydrolysis on syn-fused intermediate 25 intercepted the known lactam 28, an intermediate produced by Baran and co-workers in the course of their synthesis of 1 and more complex natural products. ${ }^{24}$

The synthesis of $\mathbf{2}$ and $\mathbf{2 8}$ constitute 12-step formal total syntheses of both brevianamide B (3) and premalbrancheamide, representative anti- and syn-fused [2.2.2] diazabicyclic alkaloid natural products. The synthetic strategy based on intermolecular pyrazinone cycloaddition is convergent and provides a direct entry to the [2.2.2] diazabicyclic feature (four to five steps from proline methyl ester). Further insight into the pyrazinone Diels-Alder was obtained in this study. In particular, we demonstrated that the use of a 2-nitroacrylate dienophile was required to obtain the desired regiochemistry. Extension of this intermolecular cycloaddition with chiral nitroacrylate derivatives ${ }^{25}$ could enable construction of structures in either enantiomeric series. Additionally, we plan to continue to explore other possible stereoselective operations, such as directed or diastereoselective reduction, in the application of this synthetic strategy to more intricate and bioactive natural products in the [2.2.2] diazabicyclic prenylated indole alkaloid family.

\section{EXPERIMENTAL SECTION}

General Information. All reactions were carried out under an atmosphere of nitrogen in flame-dried or oven-dried glassware with magnetic stirring unless otherwise indicated. Acetonitrile, THF, toluene, and $\mathrm{Et}_{2} \mathrm{O}$ were degassed with argon and purified by passage through a column of molecular sieves and a bed of activated alumina. Dichloromethane was distilled from $\mathrm{CaH}_{2}$ prior of use. All reagents were used as received unless otherwise noted. Flash column chromatography was performed using silica gel (230-400 mesh). Analytical thin-layer chromatography was performed on $60 \AA$ glass plates. Visualization was accomplished with UV light, anisaldehyde, ceric ammonium molybdate (CAM), potassium permanganate, or ninhydrin, followed by heating. ${ }^{1} \mathrm{H}$ NMR spectra were recorded on a $400 \mathrm{MHz}$ spectrometer and are reported in ppm using solvent as an internal standard $\left(\mathrm{CDCl}_{3}\right.$ at $\left.7.26 \mathrm{ppm}\right)$ or tetramethylsilane $(0.00$ ppm). Proton-decoupled ${ }^{13} \mathrm{C}$ NMR spectra were recorded on a 400 $\mathrm{MHz}$ spectrometer and are reported in ppm using solvent as an internal standard $\left(\mathrm{CDCl}_{3}\right.$ at $\left.77.0 \mathrm{ppm}\right)$. All compounds were judged to be homogeneous ( $>95 \%$ purity) by ${ }^{1} \mathrm{H}$ and ${ }^{13} \mathrm{C}$ NMR spectroscopy unless otherwise noted as mixtures. Mass spectra data analysis was obtained through positive electrospray ionization (ICR-MS w/ $\mathrm{NaCl}$ ).<smiles>O=Cc1c[nH]c2ccccc12</smiles><smiles>COC1=NCC(=O)N2CCCC12</smiles>

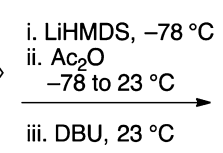<smiles>COc1nc(Cc2c[nH]c3ccccc23)c(=O)n2c1CCC2</smiles>

tert-Butyl 3-((1-Methoxy-4-oxo-4,6,7,8-tetrahydropyrrolo[1,2-a]pyrazin-3-yl)methyl)-1H-indole-1-carboxylate (14). To diketopiperazine (DKP) $\mathbf{1 2}^{8 \mathrm{~d}}(384 \mathrm{mg}, 2.29 \mathrm{mmol})$ in $\mathrm{PhMe}(8$ $\mathrm{mL})$ and DMF $(8 \mathrm{~mL})$ at $-78{ }^{\circ} \mathrm{C}$ was added LiHMDS $(2.50 \mathrm{~mL}, 1.0$ $\mathrm{M}$ in THF, 1.1 equiv) dropwise over $5 \mathrm{~min}$ by syringe. After the mixture was stirred for $15 \mathrm{~min}$ at $-78{ }^{\circ} \mathrm{C}, \mathrm{N}$-Boc-indole carboxaldehyde ( $0.56 \mathrm{~g}, 1.0$ equiv) in $\mathrm{PhMe}(8 \mathrm{~mL})$ was added, and the reaction was stirred for an additional $15 \mathrm{~min}$ at $-78{ }^{\circ} \mathrm{C} . \mathrm{Ac}_{2} \mathrm{O}$ $(0.28 \mathrm{~mL}, 3.0 \mathrm{mmol}, 1.3$ equiv) was added, and the cooling bath was removed. The reaction mixture was stirred at $\mathrm{rt}$ for $3 \mathrm{~h}$, at which time DBU ( $0.48 \mathrm{~mL}, 3.2 \mathrm{mmol}, 1.4$ equiv) was added and the reaction was stirred at $\mathrm{rt}$ for $18 \mathrm{~h}$. The reaction was then diluted with $0.1 \mathrm{M} \mathrm{HCl}$ $(50 \mathrm{~mL})$ and extracted with EtOAc $(3 \times 20 \mathrm{~mL})$. The combined organic layers were washed with satd aqueous $\mathrm{NaHCO}_{3}$ and brine, dried $\left(\mathrm{Na}_{2} \mathrm{SO}_{4}\right)$, and concentrated in vacuo. The resulting product 
(0.91 g, quant mass recovery, ca. $95 \%$ pure by ${ }^{1} \mathrm{H}$ NMR) was recrystallized (hexanes/EtOAc) to afford analytically pure $14(0.38 \mathrm{~g}$, $42 \%$ yield) as a yellow amorphous solid. Pyrazinone 14 can be stored (in the dark) for several weeks under inert gas at $-15{ }^{\circ} \mathrm{C}$ without appreciable degradation: TLC (100\% EtOAc) $R_{f} 0.40$ (UV/CAM); IR (film) 2976, 2939, 1730,1653,1584, 1579, 1452, 1369, 1349, 1256, $1157,1080,1046,1016,855,750 \mathrm{~cm}^{-1} ;{ }^{1} \mathrm{H}$ NMR $\left(400 \mathrm{MHz}, \mathrm{CDCl}_{3}\right)$ $\delta 8.10(\mathrm{~s}, 1 \mathrm{H}), 7.75(\mathrm{~d}, J=7.3 \mathrm{~Hz}, 1 \mathrm{H}), 7.61(\mathrm{~s}, 1 \mathrm{H}), 7.29-7.19(\mathrm{~m}$, $2 \mathrm{H}), 4.19(\mathrm{~s}, 2 \mathrm{H}), 4.14(\mathrm{t}, J=7.0 \mathrm{~Hz}, 2 \mathrm{H}), 3.82(\mathrm{~s}, 3 \mathrm{H}), 3.04(\mathrm{t}, J=$ $7.4 \mathrm{~Hz}, 2 \mathrm{H}), 2.21(\mathrm{q}, J=7.4 \mathrm{~Hz}, 2 \mathrm{H}), 1.65(\mathrm{~s}, 9 \mathrm{H}) ;{ }^{13} \mathrm{C} \mathrm{NMR}(100$ $\left.\mathrm{MHz}, \mathrm{CDCl}_{3}\right) \delta 154.0,149.8,149.6,142.5,135.5,130.8,125.4,124.2$, 124.1, 122.2, 120.0, 116.7, 115.0, 83.3, 54.8, 49.5, 28.4, 28.2, 28.1, 21.6; exact mass calcd for $\mathrm{C}_{22} \mathrm{H}_{25} \mathrm{~N}_{3} \mathrm{O}_{4}[\mathrm{M}+\mathrm{Na}]^{+}$418.1743, found 418.1735 .

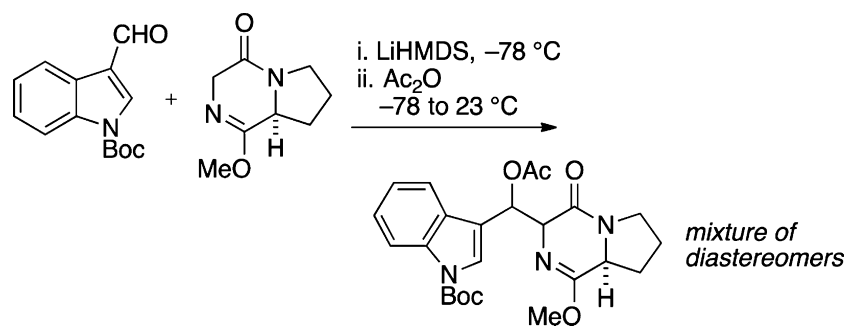

tert-Butyl 3-(Acetoxy((8aS)-1-methoxy-4-oxo-3,4,6,7,8,8ahexahydropyrrolo[1,2-a]pyrazin-3-yl)methyl)-1 $\mathrm{H}$-indole-1-carboxylate. To DKP $12(2.16 \mathrm{~g}, 12.9 \mathrm{mmol})$ in THF $(71 \mathrm{~mL})$ at -78 ${ }^{\circ} \mathrm{C}$ was added LiHMDS (14.1 mL, $1 \mathrm{M}$ in THF) dropwise and the mixture stirred for $30 \mathrm{~min}$ at $-78{ }^{\circ} \mathrm{C}$. $\mathrm{N}$-Boc-indole carboxaldehyde (3.31 g, $13.5 \mathrm{mmol})$ was added as a solution in THF $(10 \mathrm{~mL})$ dropwise over $5 \mathrm{~min}$, and the reaction was stirred for an additional 30 min at $-78{ }^{\circ} \mathrm{C} . \mathrm{Ac}_{2} \mathrm{O}(1.82 \mathrm{~mL}, 19.3 \mathrm{mmol})$ and pyridine $(1.55 \mathrm{~mL}$, $19.3 \mathrm{mmol}$ ) were each added dropwise over $5 \mathrm{~min}$, and the cold bath was removed. The reaction was allowed to warm to rt and stir for $16 \mathrm{~h}$ and was then diluted with $\mathrm{HCl}(20 \mathrm{~mL}, 0.1 \mathrm{M})$ and extracted with EtOAc $(3 \times 30 \mathrm{~mL})$. The combined organic extracts were washed with satd aqueous $\mathrm{NaHCO}_{3}(50 \mathrm{~mL})$, saturated $\mathrm{NaCl}(50 \mathrm{~mL})$, dried $\left(\mathrm{Na}_{2} \mathrm{SO}_{4}\right)$, filtered, and concentrated in vacuo to afford the $\beta$-acetoxy product as a mixture of four diastereomers. The resulting residue was purified by flash column chromatography on silica gel (gradient elution: $30 \% \rightarrow 100 \%$ EtOAc in hexanes). The four diastereomers were collected together to afford a pale yellow amorphous solid (5.32 g, $91 \%$ yield): $\mathrm{mp} 58.0-59.1{ }^{\circ} \mathrm{C}$; TLC (80\% EtOAc in hexanes) $R_{f}$ 0.25-0.35 (UV/CAM); IR (film) 2980, 2945, 2886, 1732, 1676, 1657, $1451,1368,1338,1310,1252,1219,1152,1080,1017,947,853,839$, $764,747,700,631,600,592 \mathrm{~cm}^{-1} ;{ }^{1} \mathrm{H}$ NMR $\left(400 \mathrm{MHz}, \mathrm{CDCl}_{3}\right)$ 8.13-8.01 (m, $1 \mathrm{H}), 7.96-7.91(\mathrm{~m}, 1 \mathrm{H}), 7.74-7.52(\mathrm{~m}, 1 \mathrm{H}), 7.32-$ $7.18(\mathrm{~m}, 2 \mathrm{H}), 6.89-6.41(\mathrm{~m}, 1 \mathrm{H}), 4.77-4.28(\mathrm{~m}, 1 \mathrm{H}), 4.05-3.94(\mathrm{~m}$, $1 \mathrm{H}), 3.79-3.72(\mathrm{~m}, 3 \mathrm{H}), 3.70-3.63(\mathrm{~m}, 1 \mathrm{H}), 3.50-3.31(\mathrm{~m}, 1 \mathrm{H})$, $2.31-2.22(\mathrm{~m}, 1 \mathrm{H}), 2.16-2.01(\mathrm{~m}, 3 \mathrm{H}), 1.93-1.69(\mathrm{~m}, 2 \mathrm{H}), 1.62-$ $1.29(\mathrm{~m}, 1 \mathrm{H}), 1.66-1.64(\mathrm{~m}, 9 \mathrm{H}) ;{ }^{13} \mathrm{C} \mathrm{NMR}\left(100 \mathrm{MHz}, \mathrm{CDCl}_{3}\right): \delta$ $170.2,169.8,169.4,165.9,165.5,165.2,165.1,163.4,163.1,162.5$, $162.4,149.6,149.7,149.5,135.3,135.1,129.8,129.5,128.9,128.6$, $125.6,125.4,125.0,124.7,124.6,124.4,124.3,124.1,122.7,122.6$, $122.5,122.3,121.8,120.8,120.4,120.0,118.6,116.9,116.8,116.7$, 115.2, 115.1, 114.8, 84.1, 83.6, 83.6, 71.1, 71.0, 70.4, 66.0, 65.8, 63.7, 63.4, 56.9, 56.8, 56.6, 56.3, 53.8, 53.7, 53.6, 44.6, 44.4, 44.3, 44.2, 29.6, 29.4, 29.1, 28.7, 28.3, 28.2, 28.1, 22.6, 22.4, 21.9, 21.7, 21.3, 21.2, 21.1; exact mass calcd for $\mathrm{C}_{24} \mathrm{H}_{29} \mathrm{~N}_{3} \mathrm{O}_{6} \mathrm{Na}[\mathrm{M}+\mathrm{Na}]^{+} 478.1949$, found 478.1946 .

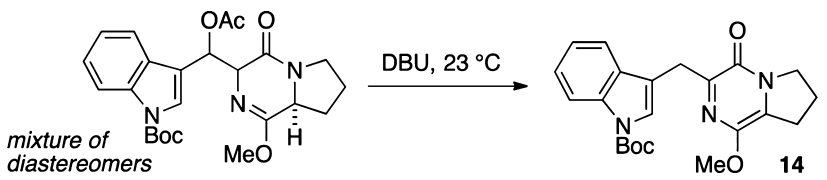

tert-Butyl 3-((1-Methoxy-4-oxo-4,6,7,8-tetrahydropyrrolo[1,2-a]pyrazin-3-yl)methyl)-1 $H$-indole-1-carboxylate (14). A flame-dried flask was charged with $\beta$-acetoxy aldol addition product $(1.37 \mathrm{~g}, 3.00 \mathrm{mmol})$, wrapped in aluminum foil, flushed with $\mathrm{N}_{2}$ gas for $10 \mathrm{~min}$, and dissolved in $\mathrm{PhMe}(15 \mathrm{~mL})$ and DMF $(3 \mathrm{~mL})$. To the reaction flask was added DBU $(0.89 \mathrm{~mL}, 6.00 \mathrm{mmol})$, and the reaction was stirred for $16 \mathrm{~h}$, diluted with $\mathrm{HCl}(20 \mathrm{~mL}, 0.2 \mathrm{M})$, and extracted with EtOAc $(3 \times 30 \mathrm{~mL})$. The combined organic extracts were washed with satd aqueous $\mathrm{NaHCO}_{3}(50 \mathrm{~mL})$ and saturated $\mathrm{NaCl}(50 \mathrm{~mL})$, dried $\left(\mathrm{Na}_{2} \mathrm{SO}_{4}\right)$, filtered, and concentrated in vacuo to afford pyrazinone 14 as a yellow amorphous solid (1.12 g, 94\% yield). Vide infra for spectral information.<smiles></smiles><smiles>CCC/C=C\C(=O)OCC</smiles>

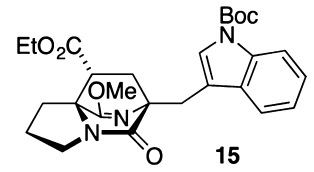

Ethyl $(6 R *, 8 R *, 8 \mathrm{a} S *)-6-((1-($ tert-Butoxycarbonyl)-1 $H$-indol-3yl)methyl)-9-methoxy-5-oxo-2,3,5,6,7,8-hexahydro- $1 \mathrm{H}-6,8 \mathrm{a}$ (azenometheno)indolizine-8-carboxylate (15). A flame-dried flask was charged with pyrazinone $14(227 \mathrm{mg}, 0.575 \mathrm{mmol})$ and fitted with a reflux condenser. The starting material was dissolved in DMF $(3.8 \mathrm{~mL}, 0.15 \mathrm{M})$, and the reaction vessel was degassed (evacuated and backfilled with $\left.\mathrm{N}_{2} \times 5\right)$. Ethyl acrylate $(0.12 \mathrm{~mL}, 114$ $\mathrm{mg}, 1.14 \mathrm{mmol}$ ) was added, and the reaction vessel was heated at 60 ${ }^{\circ} \mathrm{C}$ for $24 \mathrm{~h}$, cooled to rt, and concentrated in vacuo to afford a brown oil. Analysis of the unpurified reaction mixture reveals a 3:1:1 mixture of diastereomers. Purification by flash column chromatography on silica gel (gradient elution: $30 \% \rightarrow 100 \%$ EtOAc in hexanes) afforded product 15 (138 mg, 48\% yield) as a colorless oil: TLC (60\% EtOAc in hexane) $R_{f} 0.30$ (CAM); IR (film) 2985, 2945, 2876, 1736, 1683, 1642, 1456, 1416, 1308, 1260, 1156, 1085, 1016, 852, 768, $745 \mathrm{~cm}^{-1}$; ${ }^{1} \mathrm{H}$ NMR $\left(400 \mathrm{MHz}, \mathrm{CDCl}_{3}\right) 8.10(\mathrm{br} \mathrm{s}, 1 \mathrm{H}), 7.78(\mathrm{~d}, J=7.5 \mathrm{~Hz}, 1 \mathrm{H})$, $7.68(\mathrm{~s}, 1 \mathrm{H}), 7.24(\mathrm{~m}, 2 \mathrm{H}), 4.05(\mathrm{~m}, 2 \mathrm{H}), 3.75(\mathrm{~s}, 3 \mathrm{H}), 3.50-3.30(\mathrm{~m}$, $2 \mathrm{H}), 3.44(\mathrm{~d}, J=14.8 \mathrm{~Hz}, 1 \mathrm{H}), 3.34(\mathrm{~d}, J=14.8 \mathrm{~Hz}, 1 \mathrm{H}), 2.78(\mathrm{dd}, J=$ 9.8, $5.5 \mathrm{~Hz}, 1 \mathrm{H}), 2.61(\mathrm{~m}, 1 \mathrm{H}), 2.05-1.85(\mathrm{~m}, 4 \mathrm{H}), 1.80(\mathrm{dd}, J=13.2$, $5.5 \mathrm{~Hz}, 1 \mathrm{H}), 1.64(\mathrm{~s}, 9 \mathrm{H}), 1.18(\mathrm{t}, J=7.2 \mathrm{~Hz}, 3 \mathrm{H}) ;{ }^{13} \mathrm{C}$ NMR $(100$ $\left.\mathrm{MHz}, \mathrm{CDCl}_{3}\right) \delta 172.3,163.0,160.8,149.5,134.9,132.1,130.3,129.0$, $128.4,128.2,125.3,124.7,123.0,118.9,116.1,155.5,115.1,104.8$, 83.7, 65.6, 60.7, 54.3, 43.8, 35.0, 32.4, 29.0, 28.2, 28.1, 20.2, 14.0; exact mass calcd for $\mathrm{C}_{27} \mathrm{H}_{33} \mathrm{~N}_{3} \mathrm{O}_{6}[\mathrm{M}+\mathrm{Na}]^{+}$518.2261, found 518.2259.

Initial attempt at one-pot reaction conditions

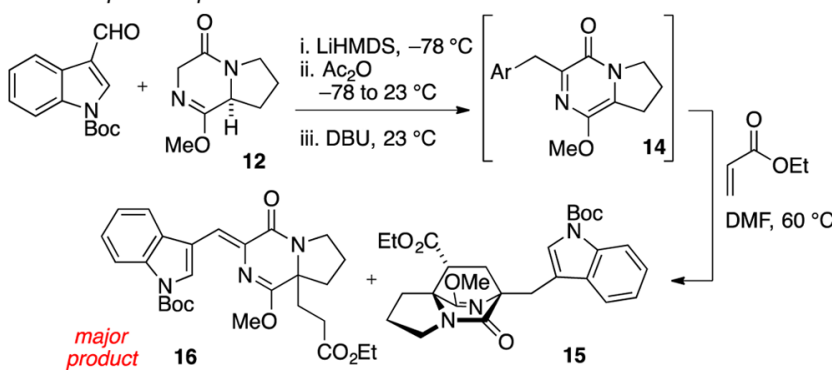

tert-Butyl (Z)-3-((8a-(3-Ethoxy-3-oxopropyl)-1-methoxy-4oxo-6,7,8,8a-tetrahydropyrrolo[1,2-a]pyrazin-3(4H)-ylidene)methyl)-1H-indole-1-carboxylate (16). The reaction was executed according to the conditions previously described for the preparation of 14. Prior to aqueous workup of $\mathbf{1 4}(0.38 \mathrm{mmol}$, assuming quantitative formation), ethyl acrylate $(0.080 \mathrm{~mL}, 0.76 \mathrm{mmol}, 2$ equiv $)$ was added, and the reaction was warmed to $60^{\circ} \mathrm{C}$ and stirred for an additional 24 h. The reaction mixture was diluted with $0.2 \mathrm{M} \mathrm{HCl}(30 \mathrm{~mL})$ and extracted with EtOAc $(3 \times 20 \mathrm{~mL})$. The combined organic layers were washed with satd aqueous $\mathrm{NaHCO}_{3}$ and brine, dried $\left(\mathrm{Na}_{2} \mathrm{SO}_{4}\right)$, and concentrated in vacuo. The resulting residue was purified by flash chromatography on silica gel (gradient elution: $40 \rightarrow 100 \%$ EtOAc in hexane) to afford 15 (28 mg, 15\% yield) and 16 (94 mg, 50\% yield) as a yellow oil. Data for compound 16: TLC (60\% EtOAc in hexane) $R_{f}$ 0.50 (UV, CAM); IR (film) 2980, 2880, 1732, 1680, 1646, 1456, 1411, $1300,1270,1154,1018,740 \mathrm{~cm}^{-1}$; ${ }^{1} \mathrm{H}$ NMR $\left(400 \mathrm{MHz}, \mathrm{CDCl}_{3}\right) ; 8.60$ (s, $1 \mathrm{H}), 8.18(\mathrm{~d}, J=7.4 \mathrm{~Hz}, 1 \mathrm{H}), 7.84(\mathrm{dd}, J=7.4,1.6 \mathrm{~Hz}, 1 \mathrm{H}), 7.34$ $(\mathrm{m}, 2 \mathrm{H}), 4.10-3.92(\mathrm{~m}, 2 \mathrm{H}), 4.01(\mathrm{~s}, 3 \mathrm{H}), 2.22-2.00(\mathrm{~m}, 8 \mathrm{H}), 3.40$ $(\mathrm{m}, 4 \mathrm{H}), 1.67(\mathrm{~s}, 9 \mathrm{H}), 1.14(\mathrm{t}, J=7.1 \mathrm{~Hz}, 3 \mathrm{H}) ;{ }^{13} \mathrm{C} \mathrm{NMR}(100 \mathrm{MHz}$, $\left.\mathrm{CDCl}_{3}\right) \delta 172.3,162.9,160.8,149.5,132.0,130.2,128.3,124.6,123.0$, $118.8,116.0,115.4,115.1,83.6,65.6,60.7,54.3,43.8,35.0,32.3$, 28.9, 
28.2, 28.0, 20.0, 14.0; exact mass calcd for $\mathrm{C}_{27} \mathrm{H}_{33} \mathrm{~N}_{3} \mathrm{O}_{6}[\mathrm{M}+\mathrm{Na}]^{+}$, 518.2261, found 518.2257.

One-pot reaction conditions
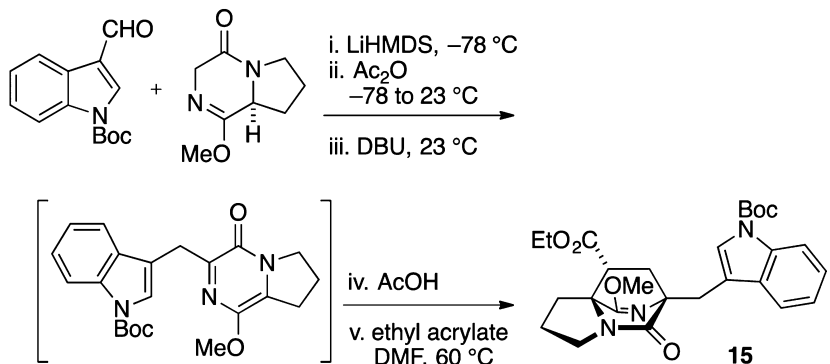

The reaction was executed according to the conditions previously described conditions used for the preparation of 14. Prior to aqueous workup of 14 ( $0.1 \mathrm{mmol}$, assuming quantitative formation), $\mathrm{AcOH}$ (6 $\mu \mathrm{L}, 0.1 \mathrm{mmol}, 1$ equiv) and ethyl acrylate $(20 \mu \mathrm{L}, 0.2 \mathrm{mmol}, 2$ equiv) were added, and the reaction was warmed to $60{ }^{\circ} \mathrm{C}$ and stirred for an additional $24 \mathrm{~h}$. The reaction mixture was diluted with $0.2 \mathrm{M} \mathrm{HCl}(10$ $\mathrm{mL})$ and extracted with EtOAc $(3 \times 10 \mathrm{~mL})$. The combined organic layers were washed with satd aqueous $\mathrm{NaHCO}_{3}$ and brine, dried $\left(\mathrm{Na}_{2} \mathrm{SO}_{4}\right)$, and concentrated in vacuo. The resulting residue was purified by flash chromatography on silica gel (gradient elution: $40 \rightarrow$ $100 \%$ EtOAc in hexane) to afford 15 (20 mg, $40 \%$ yield). Vide infra for spectral information.
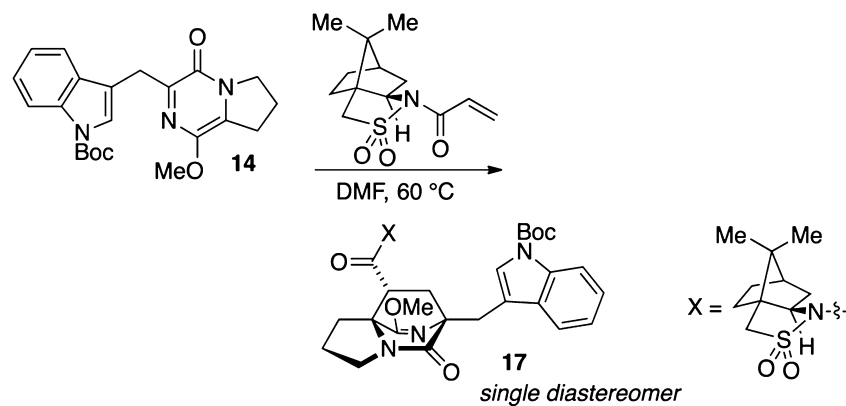

tert-Butyl 3-(((6R,8R,8aS)-8-((7aR)-8,8-Dimethyl-2,2-dioxidohexahydro-3H-3a,6-methanobenzo[c]isothiazole-1-carbonyl)9-m et h oxy-5-oxo-2, 3,7,8-tet rahydro- $1 \mathrm{H}-6,8 \mathrm{a}-$ (azenometheno)indolizin-6(5H)-yl)methyl)-1 $H$-indole-1-carboxylate (17). To a flame-dried flask were added acryloyl (+)-camphorsultam (135 mg, $0.51 \mathrm{mmol})$ and pyrazinone 14 (188 $\mathrm{mg}, 0.48 \mathrm{mmol}$ ). The flask was fitted with a condenser and flushed with $\mathrm{N}_{2}$. The reactants were dissolved in DMF $(3.2 \mathrm{~mL}, 0.15 \mathrm{M})$, and the vessel was evacuated and backfilled with $\mathrm{N}_{2}(\times 5)$ before heating to $60{ }^{\circ} \mathrm{C}$. After being heated for $24 \mathrm{~h}$, the reaction mixture was cooled to rt and concentrated in vacuo to afford a brown oil. Analysis of the unpurified reaction mixture by ${ }^{1} \mathrm{H}$ NMR reveals a single cycloadduct as well as some unreacted sultam dienophile. Purification by flash column chromatography on silica gel (gradient elution: $30 \% \rightarrow 70 \%$ EtOAc in hexanes) afforded cycloadduct $17(260 \mathrm{mg}, 62 \%$ yield $)$ as a colorless oil: TLC (80\% EtOAc in hexane) $R_{f} 0.3(\mathrm{CAM}) ;[\alpha]_{\mathrm{D}}{ }^{25}=+59(c 1.0$, $\mathrm{CH}_{2} \mathrm{Cl}_{2}$ ); IR (film) 3854, 3744, 3061, 2986, 2882, 2360, 2337, 1730 $1683,1648,1635,1452,1363,1351,1308,1298,1268,1258,1218$, $1164,1135,1083,1015,987,768,735,667,533 \mathrm{~cm}^{-1} ;{ }^{1} \mathrm{H}$ NMR (400 $\left.\mathrm{MHz}, \mathrm{CDCl}_{3}\right) 8.1(\mathrm{~s}, 1 \mathrm{H}), 7.77(\mathrm{~d}, J=1.14 \mathrm{~Hz}, 1 \mathrm{H}), 7.66(\mathrm{~s}, 1 \mathrm{H})$, $7.23(\mathrm{~m}, 2 \mathrm{H}), 3.77(\mathrm{~s}, 3 \mathrm{H}), 3.75(\mathrm{~m}, 1 \mathrm{H}), 3.52-3.42(\mathrm{~m}, 4 \mathrm{H}), 3.38(\mathrm{~d}$, $J=13.7 \mathrm{~Hz}, 1 \mathrm{H}), 3.30(\mathrm{~d}, J=14.8 \mathrm{~Hz}, 1 \mathrm{H}), 2.47(\mathrm{dd}, J=11.7,6.6 \mathrm{~Hz}$, $1 \mathrm{H}), 2.15-1.81(\mathrm{~m}, 10 \mathrm{H}), 1.68(\mathrm{dd}, J=13.3,5.5 \mathrm{~Hz}, 1 \mathrm{H}), 1.66(\mathrm{~s}$, 9H), $1.30(\mathrm{~m}, 2 \mathrm{H}), 1.15$ (s, 3H), $0.96(\mathrm{~s}, 3 \mathrm{H}) ;{ }^{13} \mathrm{C} \mathrm{NMR}(100 \mathrm{MHz}$, $\left.\mathrm{CDCl}_{3}\right) \delta 172.2,170.9,169.5,149.8,135.1,132.1,125.5,123.6,121.9$, $120.4,116.5,114.8,83.1,66.3,66.2,65.4,54.5,53.1,49.0$ 48.2, 47.7, 44.6, 43.2, 38.5, 34.9, 32.9, 28.8, 28.2, 27.2, 26.3, 24.4, 20.9, 19.8; exact mass calcd for $\mathrm{C}_{35} \mathrm{H}_{44} \mathrm{~N}_{4} \mathrm{O}_{7} \mathrm{~S}[\mathrm{M}+\mathrm{Na}]^{+}$687.2823, found 687.2813.

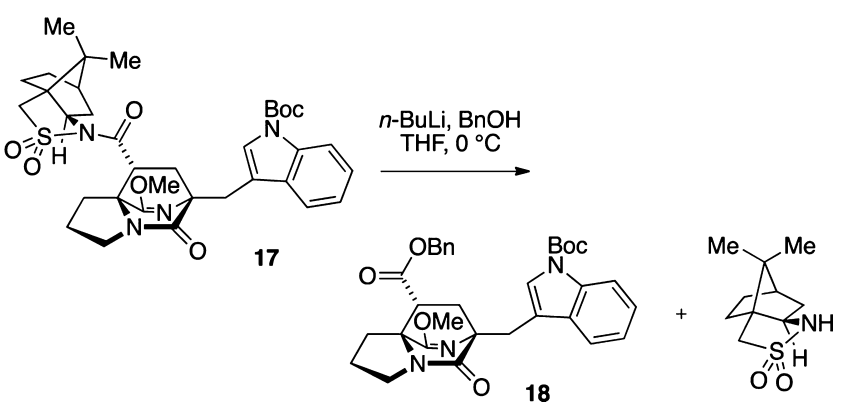

Benzyl (6R,8R,8aS)-6-((1-(tert-Butoxycarbonyl)-1H-indol-3yl)methyl)-9-methoxy-5-oxo-2,3,5,6,7,8-hexahydro- $1 \mathrm{H}-6,8 \mathrm{a}$ (azenometheno)indolizine-8-carboxylate (18). To a flame-dried reaction flask under $\mathrm{N}_{2}$ were added $\mathrm{BnOH}(13 \mu \mathrm{L}, 0.12 \mathrm{mmol})$ and THF $(0.6 \mathrm{~mL})$, the vessel was cooled to $-78{ }^{\circ} \mathrm{C}$, and a solution of $n$ $\mathrm{BuLi}(3.0 \mathrm{M}$ in pentane, $33 \mu \mathrm{L}, 0.01 \mathrm{mmol}$ ) was added. In a separate flask, sultam adduct $17(20 \mathrm{mg}, 0.03 \mathrm{mmol})$ was dissolved in THF $(0.25 \mathrm{~mL})$, and the solution was transferred via cannula to the reaction flask (which contained the LiOBn solution). After the cannula wire was rinsed with an additional $0.15 \mathrm{~mL}$ of THF, the $-78{ }^{\circ} \mathrm{C}$ cooling bath was exchanged for an ice/water bath $\left(0{ }^{\circ} \mathrm{C}\right)$. The reaction mixture was stirred at $0{ }^{\circ} \mathrm{C}$ for $8 \mathrm{~h}$, diluted with satd aq $\mathrm{NH}_{4} \mathrm{Cl}(15$ $\mathrm{mL})$, and extracted with EtOAc $(3 \times 10 \mathrm{~mL})$. The combined organic extracts were washed with satd aq $\mathrm{NaHCO}_{3}$ and brine, dried $\left(\mathrm{Na}_{2} \mathrm{SO}_{4}\right)$, and concentrated in vacuo. The resulting oil was purified by flash column chromatography on silica gel (gradient elution: $30 \%$ $\rightarrow 70 \%$ EtOAc in hexanes) to afford the benzyl ester 18 as a light yellow oil (13 mg, $75 \%$ yield): TLC (60\% EtOAc in hexane) $R_{f} 0.6$ (CAM); $[\alpha]_{\mathrm{D}}^{25}=+25$ (c 0.3, $\mathrm{CH}_{2} \mathrm{Cl}_{2}$ ); IR (film) 2985, 2942, 2882, $2358,2330,1730,1686,1639,1452,1370,1308,1257,1160,1085$, 1015, 912, 857, 746, 668, $664 \mathrm{~cm}^{-1}$; ${ }^{1} \mathrm{H}$ NMR $\left(400 \mathrm{MHz}, \mathrm{CDCl}_{3}\right)$ $8.11(\mathrm{~s}, 1 \mathrm{H}), 7.77(\mathrm{~d}, J=8.0 \mathrm{~Hz}, 1 \mathrm{H}), 7.66(\mathrm{~s}, 1 \mathrm{H}), 7.34-7.28(\mathrm{~m}$, $4 \mathrm{H}), 7.24-7.18(\mathrm{~m}, 3 \mathrm{H}) 5.06(\mathrm{~d}, J=12.1 \mathrm{~Hz}, 1 \mathrm{H}), 4.98(\mathrm{~d}, J=12.1$ $\mathrm{Hz}, 1 \mathrm{H}), 3.65(\mathrm{~s}, 3 \mathrm{H}), 3.50(\mathrm{~m}, 1 \mathrm{H}), 3.45(\mathrm{~d}, J=14.8 \mathrm{~Hz}, 1 \mathrm{H}), 3.35$ $(\mathrm{m}, 1 \mathrm{H}), 3.34(\mathrm{~d}, J=14.8 \mathrm{~Hz}, 1 \mathrm{H}), 2.84(\mathrm{dd}, J=10.2,5.5 \mathrm{~Hz}, 1 \mathrm{H})$, $2.57(\mathrm{dd}, J=13.3,5.1 \mathrm{~Hz}, 1 \mathrm{H}), 2.10-1.85(\mathrm{~m}, 4 \mathrm{H}), 1.84(\mathrm{dd}, J=13.3$, 5.5, $1 \mathrm{H}), 1.66(\mathrm{~s}, 9 \mathrm{H}) ;{ }^{13} \mathrm{C}$ NMR $\left(100 \mathrm{MHz}, \mathrm{CDCl}_{3}\right) \delta 172.4,171.4$, $169.6,135.3,132.3,128.8,125.8,124.1,122.3,120.7,116.7,115.1$, 83.4, 67.2, 66.6, 65.9, 54.6, 49.3, 43.6, 34.2, 30.6, 29.1, 28.5, 28.4, 24.9, 13.8; exact mass calcd for $\mathrm{C}_{32} \mathrm{H}_{35} \mathrm{~N}_{3} \mathrm{O}_{6}[\mathrm{M}+\mathrm{Na}]^{+} 580.2418$, found 580.2405 .

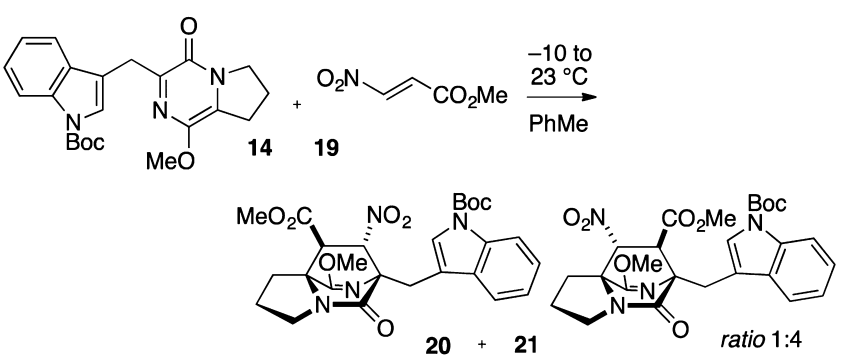

Methyl $(6 S *, 7 S *, 8 S *, 8 a S *)-6-((1-($ tert-Butoxycarbonyl)-1Hindol-3-yl)methyl)-9-methoxy-7-nitro-5-oxo-2,3,5,6,7,8-hexahydro-1H-6,8a-(azenometheno)indolizine-8-carboxylate (20) and Methyl $(6 \mathrm{~S} *, 7 R *, 8 R *, 8 \mathrm{a} S *)-6-((1$-(tert-Butoxycarbonyl)$1 \mathrm{H}$-indol-3-yl)methyl)-9-methoxy-8-nitro-5-oxo-2,3,5,6,7,8hexahydro-1 $\mathrm{H}-6,8 \mathrm{a}$-(azenometheno)indolizine-7-carboxylate (21). A dry flask was charged with pyrazinone 14 (531 mg, 1.34 $\mathrm{mmol}$ ) and flushed with $\mathrm{N}_{2}$ gas for $30 \mathrm{~min}$ and dissolved in toluene (7 $\mathrm{mL})$. A separate flask was charged with nitroacrylate 19 (158 mg, 1.21 $\mathrm{mmol}$ ) and flushed with $\mathrm{N}_{2}$ gas for $30 \mathrm{~min}$ and dissolved in toluene (2 $\mathrm{mL}$ ). The reaction flask containing pyrazinone 14 was cooled to -10 ${ }^{\circ} \mathrm{C}$ (ice/salt bath). The nitroacrylate solution was dropwise to the reaction vessel over $10 \mathrm{~min}$. The reaction was allowed to stir and slowly warm to rt overnight $(16 \mathrm{~h})$. The solution was concentrated in vacuo to afford a brown oil, which contained the two regioisomeric cycloadducts 20 and 21 in a 1:4 ratio (as judged by ${ }^{1} \mathrm{H}$ NMR on the unpurified reaction mixture). The resulting residue was purified by flash column chromatography on silica gel (gradient elution: $10 \% \rightarrow$ 
$80 \%$ EtOAc in hexanes). A small amount of pure 21 (40 mg) was obtained for analytical purposes and the bulk of the material was obtained as a yellow oil that was comprised of a 1:4 mixture of $\mathbf{2 0}$ and 21 (593 mg, 84\% yield): TLC (80\% EtOAc in hexanes) $R_{f} 0.30,0.35$ (CAM/UV). IR (film) 3052, 2980, 2950, 1733, 1704, 1641, 1608, $1559,1477,1452,1410,1370,1309,1219,1197,1158,1086,1016$, 979, 937, 897, 857, 811, 768, 747, 703, $656 \mathrm{~cm}^{-1}$; ${ }^{1} \mathrm{H}$ NMR (400 $\left.\mathrm{MHz}^{\mathrm{CDCl}}\right)_{3}: \delta 8.13(\mathrm{~d}, J=5.9 \mathrm{~Hz}, 1 \mathrm{H}), 7.76(\mathrm{~d}, J=1.6,1 \mathrm{H}), 7.74$ $(\mathrm{d}, J=7.8 \mathrm{~Hz}, 1 \mathrm{H}), 7.29(\mathrm{dt}, J=8.2,1.2 \mathrm{~Hz}, 1 \mathrm{H}) 7.21(\mathrm{dt}, J=7.8,0.8$ $\mathrm{Hz}, 1 \mathrm{H}), 5.05(\mathrm{~d}, J=4.3 \mathrm{~Hz}, 1 \mathrm{H}), 3.77(\mathrm{~s}, 3 \mathrm{H}) 3.76(\mathrm{~s}, 3 \mathrm{H}), 3.62-$ $3.52(\mathrm{~m}, 3 \mathrm{H}), 3.34(\mathrm{~d}, J=4.3 \mathrm{~Hz}, 1 \mathrm{H}), 3.30(\mathrm{~d}, J=15.7 \mathrm{~Hz}, 1 \mathrm{H})$, $2.72-2.66(\mathrm{~m}, 1 \mathrm{H}), 2.25-2.00(\mathrm{~m}, 3 \mathrm{H}), 1.68(\mathrm{~s}, 9 \mathrm{H}) ;{ }^{13} \mathrm{C}$ NMR $(100$ $\left.\mathrm{MHz}, \mathrm{CDCl}_{3}\right): \delta 169.6,169.1,168.7,149.7,135.1,132.0,125.5,124.0$, $121.9,120.5,115.3,114.9,88.9,83.3,68.6,65.3,55.4,53.1,51.0,44.0$, 28.2, 27.2, 26.8, 24.3; exact mass calcd for $\mathrm{C}_{26} \mathrm{H}_{30} \mathrm{~N}_{4} \mathrm{O}_{8} \mathrm{Na}[\mathrm{M}+\mathrm{Na}]^{+}$ 549.1953, found 549.1956.

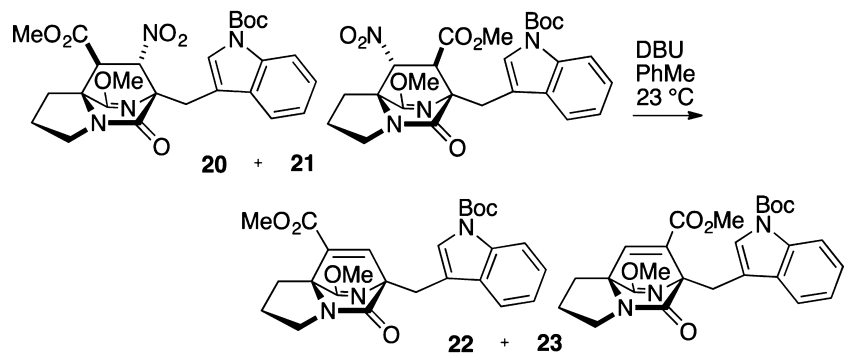

Methyl (6S*,8aS*)-6-((1-(tert-Butoxycarbonyl)-1H-indol-3yl)methyl)-9-methoxy-5-oxo-2,3,5,6-tetrahydro- $1 \mathrm{H}-6,8 \mathrm{a}$ (azenometheno)indolizine-8-carboxylate (22) and Methyl $(6 S *, 8 a S *)-6-((1-($ tert-Butoxycarbonyl)-1H-indol-3-yl)methyl)9-methoxy-5-oxo-2,3,5,6-tetrahydro-1 H-6,8a-(azenometheno)indolizine-7-carboxylate (23). A flask was charged with cycloadducts 20 and 21 (ratio 1:4, $588 \mathrm{mg}, 1.12 \mathrm{mmol}$ ), flushed with $\mathrm{N}_{2}$ gas, and dissolved in $\mathrm{PhMe}(18 \mathrm{~mL})$. To the reaction vessel was added DBU $(277 \mu \mathrm{L}, 1.86 \mathrm{mmol})$, and the reaction mixture was stirred for $16 \mathrm{~h}$ at $\mathrm{rt}$, diluted with $\mathrm{HCl}(0.1 \mathrm{M}, 10 \mathrm{~mL})$, and extracted with EtOAc $(3 \times 15 \mathrm{~mL})$. The combined organic portions were washed with saturated $\mathrm{NaHCO}_{3}(20 \mathrm{~mL})$ and saturated $\mathrm{NaCl}(20 \mathrm{~mL})$, dried $\left(\mathrm{Na}_{2} \mathrm{SO}_{4}\right)$, filtered, and concentrated in vacuo to give the $\alpha, \beta$ unsaturated methyl ester regioisomers 22 and 23 in a 1:4 ratio as judged by ${ }^{1} \mathrm{H}$ NMR on the unpurified reaction mixture. The residue was purified by flash column chromatography on silica gel (gradient elution: $20 \% \rightarrow 80 \%$ EtOAc in hexanes) to afford the minor regioisomer 22 as a light yellow oil $(62.1 \mathrm{mg}, 12 \%$ yield) and 23 as a pale yellow powder (376 mg, 70\% yield). Spectroscopic data reported for 22: TLC (40\% EtOAc in hexanes) $R_{f} 0.45$ (CAM/UV); IR (film) 2890, 2884, 1721, 1688, 1634, 1607, 1451, 1369, 1339, 1327, 1308, $1267,1256,1244,1157,1086,1044,1003,984,910,856,746,732$, $665 \mathrm{~cm}^{-1}$; ${ }^{1} \mathrm{H}$ NMR $\left(400 \mathrm{MHz}, \mathrm{CDCl}_{3}\right): \delta 8.10(\mathrm{~d}, J=7.0 \mathrm{~Hz}, 1 \mathrm{H})$, $7.83(\mathrm{~d}, J=7.5 \mathrm{~Hz}, 1 \mathrm{H}), 7.68(\mathrm{~s}, 1 \mathrm{H}), 7.50(\mathrm{~s}, 1 \mathrm{H}) 7.33-7.29(\mathrm{~m}$, $1 \mathrm{H}), 7.27-7.23(\mathrm{~m}, 1 \mathrm{H}), 3.80(\mathrm{~s}, 3 \mathrm{H}), 3.73(\mathrm{~d}, J=12.1 \mathrm{~Hz}, 3 \mathrm{H}), 3.59$ $(\mathrm{dd}, J=15.3,1.2 \mathrm{~Hz}, 2 \mathrm{H}), 3.49-3.44(\mathrm{~m}, 1 \mathrm{H}) 3.19-3.12(\mathrm{~m}, 1 \mathrm{H})$ $2.87-2.76(\mathrm{~m}, 2 \mathrm{H}) 2.14-2.04(\mathrm{~m}, 1 \mathrm{H}), 1.98-1.87(\mathrm{~m}, 1 \mathrm{H}) 1.66(\mathrm{~s}$, $9 \mathrm{H}) ;{ }^{13} \mathrm{C}$ NMR $\left(100 \mathrm{MHz}, \mathrm{CDCl}_{3}\right): \delta 175.4,169.6,162.8,152.8$, $149.8,138.2,135.1,131.7,124.9,124.1,122.3,120.0,116.1,115.0$, 83.4, 74.0, 69.4, 56.3, 51.8, 43.0, 28.2, 26.7, 25.6, 25.4; exact mass calcd for $\mathrm{C}_{26} \mathrm{H}_{29} \mathrm{~N}_{3} \mathrm{O}_{6}[\mathrm{M}+\mathrm{Na}]^{+}$502.1949, found 502.1944.

Spectroscopic data reported for $\alpha, \beta$-unsaturated methyl ester 23: mp 94.0-95.0 ${ }^{\circ} \mathrm{C}$; TLC (40\% EtOAc in hexanes) $R_{f} 0.28$ (CAM/UV); IR (film) 2980, 2949, 2882, 1722, 1690, 1640, 1607, 1451, 1370, 1339, 1304, 1256, 1221, 1155, 1080, 1017, 995, 978, 930, 907, 856, 835, 764, 739, $619 \mathrm{~cm}^{-1}$; ${ }^{1} \mathrm{H}$ NMR $\left(400 \mathrm{MHz}, \mathrm{CDCl}_{3}\right): \delta 8.06(\mathrm{~s}, 1 \mathrm{H}), 7.81$ (dd, $J=7.1,1.3 \mathrm{~Hz}, 1 \mathrm{H}), 7.62(\mathrm{~s}, 1 \mathrm{H}), 7.28-7.20(\mathrm{~m}, 2 \mathrm{H}), 7.13(\mathrm{~s}$, $1 \mathrm{H}), 4.07(\mathrm{dd}, J=15.6,0.8 \mathrm{~Hz}, 1 \mathrm{H}), 3.79(\mathrm{~s}, 3 \mathrm{H}), 3.64(\mathrm{dd}, J=15.6$, $0.8 \mathrm{~Hz}, 1 \mathrm{H}), 3.40(\mathrm{~s}, 3 \mathrm{H}), 3.40-3.35(\mathrm{~m}, 1 \mathrm{H}), 3.25-3.19(\mathrm{~m}, 1 \mathrm{H})$, $2.74(\mathrm{~m}, 1 \mathrm{H}), 2.25-2.18(\mathrm{~m}, 1 \mathrm{H}), 2.10-2.00(\mathrm{~m}, 2 \mathrm{H}), 1.63(\mathrm{~s}, 9 \mathrm{H})$; ${ }^{13} \mathrm{C}$ NMR $\left(100 \mathrm{MHz}, \mathrm{CDCl}_{3}\right): \delta 174.4,169.7,164.6,150.0,147.5$, 144.4, 135.1, 132.3, 124.5, 124.0, 122.1, 120.7, 117.6, 114.9, 83.1, 75.7, 67.6, 56.3, 52.1, 42.7, 28.4, 26.8, 25.5, 25.3; exact mass calcd for $\mathrm{C}_{26} \mathrm{H}_{29} \mathrm{~N}_{3} \mathrm{O}_{6}[\mathrm{M}+\mathrm{Na}]^{+}$502.1949, found 502.1944.
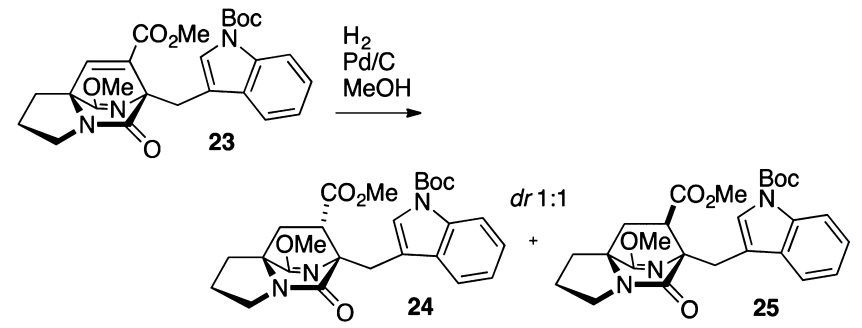

Methyl $(6 S *, 7 S *, 8 \mathrm{a} S *)-6-((1-($ tert-Butoxycarbonyl)-1 $\mathrm{H}$-indol3-yl)methyl)-9-methoxy-5-oxo-2,3,5,6,7,8-hexahydro- $1 \mathrm{H}-6,8 \mathrm{a}$ (azenometheno)indolizine-7-carboxylate (24) and Methyl $(6 S *, 7 R *, 8 \mathrm{a} S *)-6-((1-($ tert-Butoxycarbonyl)-1H-indol-3-yl)methyl)-9-methoxy-5-oxo-2,3,5,6,7,8-hexahydro-1 $\mathrm{H}-6,8 \mathrm{a}-$ (azenometheno)indolizine-7-carboxylate (25). Unsaturated ester $23(182 \mathrm{mg}, 0.378 \mathrm{mmol})$ was dissolved in $\mathrm{MeOH}(4 \mathrm{~mL})$ at $\mathrm{rt}$, and $10 \% \mathrm{Pd} / \mathrm{C}(25 \mathrm{mg})$ was added. One balloon of $\mathrm{H}_{2}$ gas was used to sparge the reaction mixture $(10 \mathrm{~min})$; a second balloon was maintained above the reaction mixture during the course of the reaction to provide an atmosphere of $\mathrm{H}_{2}$. When TLC indicated consumption of starting material $(1 \mathrm{~h})$, the reaction mixture was filtered through Celite, and the filter pad was washed with $\mathrm{MeOH}$. After removal of the solvent in vacuo, a white powder was obtained that contained an equal mixture of diastereomers as judged by ${ }^{1} \mathrm{H}$ NMR on the unpurified reaction mixture. The mixture was purified by flash chromatography on silica gel (20\% to $100 \%$ EtOAc in hexanes) to afford 24 (77 mg, 43\% yield) and 25 (78 mg, 43\% yield), both obtained as a colorless amorphous solids. Spectroscopic data for 24: TLC (60\% EtOAC in hexanes) $R_{f} 0.36$ (CAM/UV); IR (film) 2980, 2948, 2883, 1732, 1730, 1695, 1687, 1641, 1476, 1457, 1452, 1416, $1371,1360,1308,1257,1213,1185,1161,1084,1016,913,857,768$, $745,701,672 \mathrm{~cm}^{-1} ;{ }^{1} \mathrm{H}$ NMR $\left(400 \mathrm{MHz}, \mathrm{CDCl}_{3}\right): \delta 8.07(\mathrm{~d}, J=5.8$ $\mathrm{Hz}, 1 \mathrm{H}), 7.76(\mathrm{~s}, 1 \mathrm{H}), 7.74(\mathrm{~d}, J=2.0 \mathrm{~Hz}, 1 \mathrm{H}), 7.24-7.19(\mathrm{~m}, 2 \mathrm{H})$, $3.78(\mathrm{~s}, 3 \mathrm{H}), 3.54(\mathrm{~d}, J=14.8 \mathrm{~Hz}, 1 \mathrm{H}), 3.47(\mathrm{~s}, 3 \mathrm{H}), 3.44-3.31(\mathrm{~m}$, $2 \mathrm{H}), 3.22(\mathrm{~d}, J=14.9 \mathrm{~Hz}, 1 \mathrm{H}), 3.06(\mathrm{q}, J=4.7 \mathrm{~Hz}, 1 \mathrm{H}), 2.65-2.58$ (m, 1H), 2.09-1.87 (m, 5H), $1.63(\mathrm{~s}, 9 \mathrm{H}) ;{ }^{13} \mathrm{C}$ NMR $(100 \mathrm{MHz}$, $\left.\mathrm{CDCl}_{3}\right): \delta 172.4,171.0,169.9,149.9,134.9,132.3,125.7,123.6,121.9$, 120.3 , 116.7, 114.8, 82.8, 69.3, 64.1, 54.7, 51.8, 45.8, 43.4, 37.3, 28.6, 28.2, 27.5, 24.4; exact mass calcd for $\mathrm{C}_{26} \mathrm{H}_{31} \mathrm{~N}_{3} \mathrm{O}_{6} \mathrm{Na}[\mathrm{M}+\mathrm{Na}]^{+}$ 504.2105, found 504.2102.

Spectroscopic data for 25: TLC (60\% EtOAC in hexanes) $R_{f} 0.43$, (CAM/UV); IR (film) 2979, 2948, 2881, 1731, 1693, 1690, 1689, $1452,1437,1419,1370,1343,1301,1258,1218,1162,1120,1084$, 1045, 1013, 990, 856, 767, 747, $666 \mathrm{~cm}^{-1}$; ${ }^{1} \mathrm{H}$ NMR $(400 \mathrm{MHz}$, $\left.\mathrm{CDCl}_{3}\right): \delta 8.09(\mathrm{~s}, 1 \mathrm{H}), 7.79(\mathrm{~d}, J=7.8 \mathrm{~Hz}, 1 \mathrm{H}), 7.68(\mathrm{~s}, 1 \mathrm{H}), 7.25(\mathrm{t}$, $J=6.2 \mathrm{~Hz}, 1 \mathrm{H}), 7.19(\mathrm{t}, J=7.8 \mathrm{~Hz}, 1 \mathrm{H}), 3.75(\mathrm{~s}, 1 \mathrm{H}), 3.71(\mathrm{~s}, 3 \mathrm{H})$, $3.68(\mathrm{~s}, 3 \mathrm{H}), 3.29(\mathrm{~d}, J=15.3 \mathrm{~Hz}, 1 \mathrm{H}), 2.76(\mathrm{q}, J=5.1 \mathrm{~Hz}, 1 \mathrm{H}), 2.60-$ $2.54(\mathrm{~m}, 1 \mathrm{H}), 2.08-1.83(\mathrm{~m}, 5 \mathrm{H}), 1.66(\mathrm{~s}, 9 \mathrm{H}) ;{ }^{13} \mathrm{C} \mathrm{NMR}(100 \mathrm{MHz}$, $\left.\mathrm{CDCl}_{3}\right): \delta 172.9,172.4,169.8,149.9,135.2,132.3,125.5,123.8,121.8$, 121.1, 116.5, 114.8, 83.1, 68.9, 63.3, 54.7, 52.1, 45.2, 43.5, 36.3, 28.7, 28.2, 27.2, 24.6; exact mass calcd for $\mathrm{C}_{26} \mathrm{H}_{31} \mathrm{~N}_{3} \mathrm{O}_{6} \mathrm{Na}[\mathrm{M}+\mathrm{Na}]^{+}$ 504.2105 , found 504.2102 .

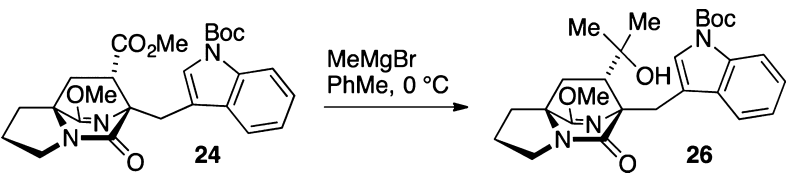

tert-Butyl 3-(((6S*,7S*,8aS*)-7-(2-Hydroxypropan-2-yl)-9methoxy-5-oxo-2,3,7,8-tetrahydro-1 $\mathrm{H}$-6,8a-(azenometheno)indolizin-6(5H)-yl)methyl)-1H-indole-1-carboxylate (26). A flame-dried flask was charged with $24(12.5 \mathrm{mg}, 0.026 \mathrm{mmol})$ and flushed with $\mathrm{N}_{2}$ gas for $10 \mathrm{~min}$, dissolved in toluene $(0.52 \mathrm{~mL})$, and cooled to $0{ }^{\circ} \mathrm{C}$. To this solution was added $\mathrm{MeMgBr}(74 \mu \mathrm{L}, 0.104$ $\mathrm{mmol}, 1.4 \mathrm{M}$ in THF). The reaction was stirred for $1 \mathrm{~h}$ at $0{ }^{\circ} \mathrm{C}$, diluted with $\mathrm{NH}_{4} \mathrm{Cl}(10 \mathrm{~mL})$, and extracted with EtOAc $(3 \times 10 \mathrm{~mL})$. The combined organic layers were washed with saturated $\mathrm{NaCl}(40 \mathrm{~mL})$, dried $\left(\mathrm{Na}_{2} \mathrm{SO}_{4}\right)$, filtered, and concentrated in vacuo. The resulting product was purified by flash chromatography on silica gel $(50 \% \rightarrow$ $100 \%$ EtOAc in hexanes) to afford the derived lactim tertiary alcohol 26 as a white foam ( $7.4 \mathrm{mg}$, 59\% yield): TLC ( $80 \%$ EtOAc in hexanes) 
$R_{f} 0.35$ (CAM/UV); IR (film) 3406, 2976, 2945, 2880, 1726, 1661, $1451,1424,1368,1354,1256,1207,1155,1103,1080,1011,955,924$, 924, 856, 820, $743 \mathrm{~cm}^{-1}$; ${ }^{1} \mathrm{H}$ NMR $\left(400 \mathrm{MHz}, \mathrm{CDCl}_{3}\right) \delta 8.05$ (br s, $1 \mathrm{H}), 7.84-7.82(\mathrm{~m}, 1 \mathrm{H}), 7.69(\mathrm{~s}, 1 \mathrm{H}), 7.24-7.18(\mathrm{~m}, 2 \mathrm{H}), 3.75(\mathrm{~d}, J$ $=14.8 \mathrm{~Hz}, 1 \mathrm{H}), 3.69(\mathrm{~s}, 3 \mathrm{H}), 3.51(\mathrm{~d}, J=14.9 \mathrm{~Hz}, 1 \mathrm{H}), 3.47-3.41(\mathrm{~m}$, $1 \mathrm{H}), 3.28-3.22(\mathrm{~m}, 1 \mathrm{H}), 2.50(\mathrm{dt}, J=12.9,7.4 \mathrm{~Hz}, 1 \mathrm{H}), 2.35(\mathrm{dd}, J=$ 9.8, $6.2 \mathrm{~Hz}, 1 \mathrm{H}), 2.04(\mathrm{dd}, J=12.9,9.8,1 \mathrm{H}), 1.97-1.82(\mathrm{~m}, 3 \mathrm{H}), 1.76$ (br s, $1 \mathrm{H}), 1.63(\mathrm{~s}, 9 \mathrm{H}), 1.41(\mathrm{dd}, J=12.9,6.2 \mathrm{~Hz}, 1 \mathrm{H}), 1.32(\mathrm{~s}, 3 \mathrm{H})$, $1.22(\mathrm{~s}, 3 \mathrm{H}) ;{ }^{13} \mathrm{C}\left(100 \mathrm{MHz}, \mathrm{CDCl}_{3}\right) \delta 171.5,169.8,150.0,134.8$, 132.6, 125.5, 123.3, 121.7, 120.7, 118.8, 114.7, 82.7, 74.2, 71.7, 63.4, 54.1, 51.9, 43.2, 37.9, 31.2, 28.6, 28.2, 25.9, 24.2; exact mass calcd for $\mathrm{C}_{27} \mathrm{H}_{35} \mathrm{~N}_{3} \mathrm{O}_{5} \mathrm{Na}[\mathrm{M}+\mathrm{Na}]^{+}$504.2469, found 504.2468.
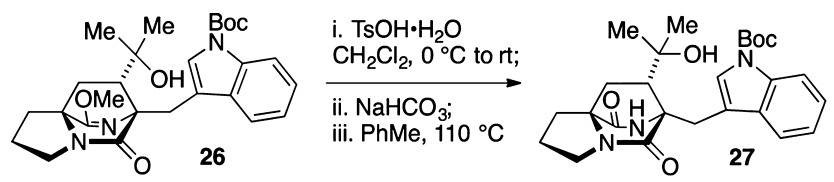

tert-Butyl 3-(((6S,7S,8aS)-7-(2-Hydroxypropan-2-yl)-5,9-dioxotetrahydro- $1 H-6,8 a-(e p i m i n o m e t h a n o)$ indolizin- $6(5 H)$-yl)methyl)-1H-indole-1-carboxylate (27). A reaction flask was charged with lactim tertiary alcohol $26(15.8 \mathrm{mg}, 0.033 \mathrm{mmol})$ and flushed with $\mathrm{N}_{2}$ gas for $10 \mathrm{~min}$, dissolved in $\mathrm{CH}_{2} \mathrm{Cl}_{2}(3.5 \mathrm{~mL})$, and cooled to $0{ }^{\circ} \mathrm{C}$. To the reaction flask was added $p-\mathrm{TsOH} \cdot \mathrm{H}_{2} \mathrm{O}(7.3 \mathrm{mg}$, $0.038 \mathrm{mmol})$. The reaction was stirred and slowly warmed to ambient temperature over $6 \mathrm{~h}$. The reaction mixture was diluted with satd aq $\mathrm{NaHCO}_{3}(10 \mathrm{~mL})$, and extracted with EtOAc $(4 \times 10 \mathrm{~mL})$. The combined organic layers were washed with saturated $\mathrm{NaCl}(40 \mathrm{~mL})$, dried $\left(\mathrm{Na}_{2} \mathrm{SO}_{4}\right)$, filtered, and concentrated in vacuo. The resulting product (which contained some amino methyl ester) was dissolved in toluene $(3 \mathrm{~mL})$ and stirred at $110{ }^{\circ} \mathrm{C}$ for $18 \mathrm{~h}$. The solution was concentrated in vacuo to obtain lactam tertiary alcohol $27(15.5 \mathrm{mg}$, $95 \%$ yield) which was used without further purification: TLC $(80 \%$ EtOAc in hexanes) $R_{f} 0.32$ (CAM/UV); IR (film) 3393, 2928, 1688, $1682,1674,1451,1367,1339,1310,1258,1221,1153,1085,1022$, 961, 934, 856, 802, 745, 694, 665, $592 \mathrm{~cm}^{-1}$; ${ }^{1} \mathrm{H}$ NMR (400 MHz, $\left.\mathrm{CDCl}_{3}\right) \delta 8.12(\mathrm{~d}, J=7.4 \mathrm{~Hz}, 1 \mathrm{H}), 7.64(\mathrm{~s}, 1 \mathrm{H}), 7.60(\mathrm{~d}, J=7.1 \mathrm{~Hz}$, $1 \mathrm{H}), 7.33-7.16(\mathrm{~m}, 2 \mathrm{H}), 5.70($ br s, $1 \mathrm{H}), 4.01(\mathrm{~d}, J=15.6 \mathrm{~Hz}, 1 \mathrm{H})$, $3.64-3.52(\mathrm{~m}, 2 \mathrm{H}), 3.40(\mathrm{dt}, J=11.8,6.6 \mathrm{~Hz}, 1 \mathrm{H}), 2.65(\mathrm{dt}, J=12.9$, $7.4 \mathrm{~Hz}, 1 \mathrm{H}), 2.36(\mathrm{~s}, 1 \mathrm{H}), 2.31(\mathrm{dd}, J=10.2,6.6 \mathrm{~Hz}, 1 \mathrm{H}), 2.13(\mathrm{dd}, J$ $=13.3,10.2 \mathrm{~Hz}, 1 \mathrm{H}$ ), 1.97 (apparent quint, $J=7.0 \mathrm{~Hz}, 2 \mathrm{H}$ ), $1.82-1.74$ $(\mathrm{m}, 2 \mathrm{H}), 1.66(\mathrm{~s}, 9 \mathrm{H}), 1.45(\mathrm{~s}, 3 \mathrm{H}), 1.30(\mathrm{~s}, 3 \mathrm{H}) ;{ }^{13} \mathrm{C}$ NMR $(100$ $\left.\mathrm{MHz}, \mathrm{CDCl}_{3}\right) \delta 172.4,169.3,149.6,135.1,131.5,126.8,124.5,122.9$, 118.0, 115.5, 114.6, 83.7, 73.8, 66.8, 65.8, 50.7, 44.2, 36.2, 32.0, 28.2, 24.1, 23.7, 23.5; exact mass calcd for $\mathrm{C}_{26} \mathrm{H}_{33} \mathrm{~N}_{3} \mathrm{O}_{5} \mathrm{Na}[\mathrm{M}+\mathrm{Na}]^{+}$ 490.2312, found 490.2312 .
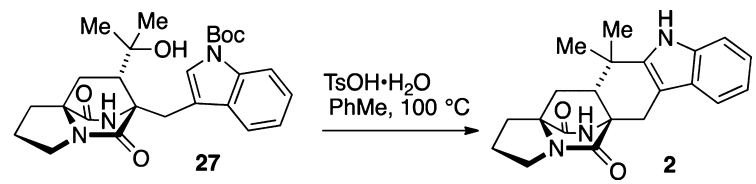

12,12-Dimethyl-2,3,11,12,12a,13-hexahydro- $1 \mathrm{H}, 5 \mathrm{H}, 6 \mathrm{H}$ $5 a, 13 a-(e p i m i n o m e t h a n o)$ indolizino[ $7,6-b]$ carbazole-5, 14dione (2). A reaction flask was charged with lactam tertiary alcohol 27 (11.5 mg, $0.025 \mathrm{mmol}$ ), fitted with a reflux condenser, and flushed with $\mathrm{N}_{2}$ gas for $10 \mathrm{~min}$. $\mathrm{PhMe}(3.7 \mathrm{~mL})$ and $p-\mathrm{TsOH} \cdot \mathrm{H}_{2} \mathrm{O}(4.7 \mathrm{mg}$, $0.025 \mathrm{mmol}$ ) were added, and the reaction vessel was heated to 100 ${ }^{\circ} \mathrm{C}$ for $6 \mathrm{~h}$. After being cooled to rt, the reaction was diluted with satd aqueous $\mathrm{NaHCO}_{3}(10 \mathrm{~mL})$ and extracted with EtOAc $(3 \times 10 \mathrm{~mL})$. The combined organic layers were washed with saturated $\mathrm{NaCl}(40$ $\mathrm{mL})$, dried $\left(\mathrm{Na}_{2} \mathrm{SO}_{4}\right)$, filtered, and concentrated in vacuo to obtain 2 as a white powder ( $7.1 \mathrm{mg}, 83 \%$ yield). The material thus obtained was $>95 \%$ pure as judged by ${ }^{1} \mathrm{H}$ NMR and further purification was not performed: TLC (100\% EtOAc) $R_{f} 0.45$ (CAM/UV); IR (film) 3325, 3310, 3233, 3221, 3210, 2990, 2947, 2901, 1656, 1670, 1451, 1404, $1369,1339,1300,1258,1196,1161,1092,1011,922,860,802,772$, 748, 718, 698, 644, 594; ${ }^{1} \mathrm{H}$ NMR $\left(400 \mathrm{MHz}, \mathrm{CDCl}_{3}\right) \delta 7.89$ (br s, $1 \mathrm{H}), 7.52(\mathrm{~d}, J=7.8 \mathrm{~Hz}, 1 \mathrm{H}), 7.32(\mathrm{~d}, J=7.9 \mathrm{~Hz}, 1 \mathrm{H}), 7.18(\mathrm{td}, J=$ 7.5, $1.3 \mathrm{~Hz}, 1 \mathrm{H}), 7.12(\mathrm{td}, J=7.5,1.2 \mathrm{~Hz}, 1 \mathrm{H}), 5.88($ br s, $1 \mathrm{H}), 3.93$ $(\mathrm{d}, J=18 \mathrm{~Hz}, 1 \mathrm{H}), 3.54(\mathrm{t}, J=6.9 \mathrm{~Hz}, 2 \mathrm{H}), 2.91(\mathrm{~d}, J=18 \mathrm{~Hz}, 1 \mathrm{H})$,
2.81 (quint, $J=6.7 \mathrm{~Hz}, 1 \mathrm{H}), 2.34(\mathrm{dd}, J=9.8,4.3 \mathrm{~Hz}, 1 \mathrm{H}), 2.18-1.99$ (m, 4H), 1.89-1.82 (m, 1H), $1.33(\mathrm{~s}, 3 \mathrm{H}), 1.28(\mathrm{~s}, 3 \mathrm{H}) ;{ }^{13} \mathrm{C} \mathrm{NMR}$ $\left(100 \mathrm{MHz}, \mathrm{CDCl}_{3}\right) \delta 172.7,169.0,139.6,136.4,127.2,122.1,119.7$, $118.3,110.7,103.6,67.1,61.6,45.7,44.2,34.5,32.6,29.1,29.0,25.3$, 24.5, 23.9. exact mass calcd for spray dimer $\mathrm{C}_{42} \mathrm{H}_{46} \mathrm{~N}_{6} \mathrm{O}_{4} \mathrm{Na}[\mathrm{M}+\mathrm{M}+$ $\mathrm{Na}]^{+} 721.3473$, found 721.3476 . The spectral data for 2 were identical with an authentic sample provided by Williams (Colorado State University).
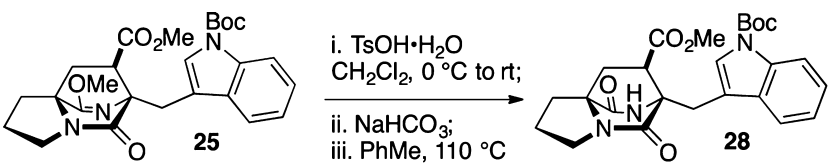

Methyl (6S,7R,8aS)-6-((1-(tert-Butoxycarbonyl)-1H-indol-3yl)methyl)-5,9-dioxohexahydro- $1 \mathrm{H}-6,8 \mathrm{a}$-(epiminomethano)indolizine-7-carboxylate (28). A reaction flask was charged with lactim methyl ester 25 (48 mg, $0.099 \mathrm{mmol})$ and flushed with $\mathrm{N}_{2}$ gas for $10 \mathrm{~min}$, dissolved in $\mathrm{CH}_{2} \mathrm{Cl}_{2}(10 \mathrm{~mL})$, and cooled to $0{ }^{\circ} \mathrm{C}$. To the reaction flask was added $p \mathrm{TsOH} \cdot \mathrm{H}_{2} \mathrm{O}(24 \mathrm{mg}, 0.13 \mathrm{mmol})$, and the reaction was stirred for $6 \mathrm{~h}$ while slowly warming to rt. The reaction mixture was diluted with satd aq $\mathrm{NaHCO}_{3}(10 \mathrm{~mL})$ and extracted with EtOAc $(4 \times 10 \mathrm{~mL})$. The combined organic layers were washed with saturated $\mathrm{NaCl}(40 \mathrm{~mL})$, dried $\left(\mathrm{Na}_{2} \mathrm{SO}_{4}\right)$, filtered, and concentrated in vacuo. The resulting product (which contained some amino methyl ester) was dissolved in toluene $(10 \mathrm{~mL})$ and stirred at $110^{\circ} \mathrm{C}$ for $18 \mathrm{~h}$. The solution was concentrated in vacuo to obtain the lactam 28 as a white powder ( $15.7 \mathrm{mg}, 88 \%$ yield). The material thus obtained was $>95 \%$ pure as judged by ${ }^{1} \mathrm{H}$ NMR, and further purification was not performed: TLC (70\% EtOAc in hexanes) $R_{f} 0.30$ (CAM/UV); IR (film) 3175, 3117, 3082, 3051, 2978, 2936, 2882, 1736, 1724, 1690, 1450, 1385, 1362, 1312, 1254, 1196, 1153, 1092, 1308, 1018, 964, 934, 922, 899, 849, 837, 768, 745, 691, 563; ${ }^{1} \mathrm{H}$ NMR $\left(400 \mathrm{MHz}, \mathrm{CDCl}_{3}\right) \delta$ $8.15(\mathrm{~d}, J=8.2 \mathrm{~Hz}, 1 \mathrm{H}), 7.71(\mathrm{~s}, 1 \mathrm{H}), 7.59$ (d, $J=7.5 \mathrm{~Hz}, 1 \mathrm{H}), 7.36$ $(\mathrm{td}, J=7.6,1.2 \mathrm{~Hz}, 1 \mathrm{H}), 7.29(\mathrm{td}, J=7.6,1.2 \mathrm{~Hz}, 1 \mathrm{H}), 5.75(\mathrm{br} \mathrm{s}, 1 \mathrm{H})$, $3.82(\mathrm{~s}, 3 \mathrm{H}), 3.66-3.53(\mathrm{~m}, 3 \mathrm{H}), 3.30(\mathrm{dd}, J=9.8,4.7 \mathrm{~Hz}, 1 \mathrm{H}), 3.19$ $(\mathrm{d}, J=15.6 \mathrm{~Hz}, 1 \mathrm{H}), 2.73-2.66(\mathrm{~m}, 1 \mathrm{H}), 2.28--2.15(\mathrm{~m}, 2 \mathrm{H}), 2.10-$ $1.98(\mathrm{~m}, 2 \mathrm{H}), 1.85-1.79(\mathrm{~m}, 1 \mathrm{H}), 1.69(\mathrm{~s}, 9 \mathrm{H}) ;{ }^{13} \mathrm{C}$ NMR $(100 \mathrm{MHz}$, $\left.\mathrm{CDCl}_{3}\right) \delta 172.3,171.6,166.4,149.4,135.4,130.8,126.2,125.0,123.3$ $118.1,115.7,112.4,84.1,66.1,63.4,52.7,48.2,44.3,34.8,28.9,28.2$, 24.3, 24.0.exact mass calcd for $\mathrm{C}_{25} \mathrm{H}_{29} \mathrm{~N}_{3} \mathrm{O}_{6} \mathrm{Na}[\mathrm{M}+\mathrm{Na}]^{+}$490.1949, found 490.1948 . Spectral data agrees with that reported by Baran. ${ }^{24}$

\section{ASSOCIATED CONTENT}

\section{Supporting Information}

The Supporting Information is available free of charge on the ACS Publications website at DOI: 10.1021/acs.joc.5b02744.

Spectroscopic data ( ${ }^{1} \mathrm{H}$ NMR and ${ }^{13} \mathrm{C}$ NMR) for all new compounds as well as known compounds 2 and 28 (PDF)

\section{AUTHOR INFORMATION}

\section{Corresponding Author}

*E-mail: jrscheerer@wm.edu.

\section{Notes}

The authors declare no competing financial interest.

\section{ACKNOWLEDGMENTS}

We thank Professor Robert M. Williams (Colorado State University) for authentic samples of $\mathbf{1}$ and $\mathbf{2}$. We acknowledge primary support from the National Institutes of Health (R15 GM107702 to J.R.S.). The donors of the ACS Petroleum Research Fund supported early aspects of this work. Support was also provided by the Camille and Henry Dreyfus Foundation (Henry Dreyfus Teacher-Scholar Award to J.R.S.). The NSF MRI provided funds for the acquisition and 
upgrade of a $400 \mathrm{MHz}$ NMR Spectrometer (Award No. 1337295).

\section{REFERENCES}

(1) (a) Birch, A. J.; Wright, J. J. J. Chem. Soc., Chem. Commun. 1969, 644-645. (b) Birch, A. J.; Russell, R. A. Tetrahedron 1972, 28, 29993008.

(2) Finefield, J. M.; Frisvad, J. C.; Sherman, D. H.; Williams, R. M. J. Nat. Prod. 2012, 75, 812-833.

(3) (a) Qian-Cutrone, J.; Huang, S.; Shu, Y. Z.; Vyas, D.; Fairchild, C.; Menendez, A.; Krampitz, K.; Dalterio, R.; Klohr, S. E.; Gao, Q. J. Am. Chem. Soc. 2002, 124, 14556-14557. (b) Martínez-Luis, S.; Rodríguez, R.; Acevedo, L.; González, M. C.; Lira-Rocha, A.; Mata, R. Tetrahedron 2006, 62, 1817-1822. (c) Lin, Z.; Wen, J.; Zhu, T.; Fang, Y.; Gu, Q.; Zhu, W. J. Antibiot. 2008, 61, 81-85.

(4) The syn/anti nomeclature was introduced by Williams. For a more detailed desciption see ref 2.

(5) (a) Tsukamoto, S.; Kawabata, T.; Kato, H.; Greshock, T. J.; Hirota, H.; Ohta, T.; Williams, R. M. Org. Lett. 2009, 11, 1297-1300. (b) Sunderhaus, J. D.; Sherman, D. H.; Williams, R. M. Isr. J. Chem. 2011, 51, 442-452.

(6) Cai, S.; Luan, Y.; Kong, X.; Zhu, T.; Gu, Q.; Li, D. Org. Lett. 2013, 15, 2168-2171.

(7) The synthesis of [2.2.2] diazabicycles has been reviewed: Miller, K. A.; Williams, R. M. Chem. Soc. Rev. 2009, 38, 3160-3174.

(8) Additional strategies not encompassed in the review: (a) Frebault, F. C.; Simpkins, N. S. Tetrahedron 2010, 66, 6585-6596. (b) Crick, P. J.; Simpkins, N. S.; Highton, A. Org. Lett. 2011, 13, 6472-6475. (c) Simpkins, N.; Pavlakos, I.; Male, L. Chem. Commun. 2012, 48, 1958-1960. (d) Laws, S. W.; Scheerer, J. R. J. Org. Chem. 2013, 78, 2422-2429. (e) Simpkins, N. S.; Pavlakos, I.; Weller, M. D.; Male, L. Org. Biomol. Chem. 2013, 11, 4957-4970. (f) Mercado-Marin, E. V.; Sarpong, R. Chem. Sci. 2015, 6, 5048-5052. (g) Amatov, T.; Pohl, R.; Cisarova, I.; Jahn, U. Angew. Chem., Int. Ed. 2015, 54, 12153-12157.

(9) Ding, Y.; Greshock, T. J.; Miller, K. A.; Sherman, D. H.; Williams, R. M. Org. Lett. 2008, 10, 4863-4866.

(10) (a) Adams, L. A.; Valente, M. W. N.; Williams, R. M. Tetrahedron 2006, 62, 5195-5200. (b) Williams, R. M.; Glinka, T.; Kwast, E. J. Am. Chem. Soc. 1988, 110, 5927-5929. (c) Williams, R. M.; Glinka, T.; Kwast, E.; Coffman, H.; Stille, J. K. J. Am. Chem. Soc. 1990, 112, 808-821.

(11) (a) Miller, K. A.; Tsukamoto, S.; Williams, R. M. Nat. Chem. 2009, 1, 63-68. (b) Finefield, J. M.; Kato, H.; Greshock, T. J.; Sherman, D. H.; Tsukamoto, S.; Williams, R. M. Org. Lett. 2011, 13, 3802-3805. (c) Williams, R. M. J. Org. Chem. 2011, 76, 4221-4259. (d) Williams, R. M.; Cox, R. J. Acc. Chem. Res. 2003, 36, 127-139.

(12) Sanz-Cervera, J. F.; Williams, R. M. J. Am. Chem. Soc. 2002, 124, 2556-2559.

(13) Sprague, D. J.; Nugent, B. M.; Yoder, R. A.; Vara, B. A.; Johnston, J. N. Org. Lett. 2015, 17, 880-883.

(14) Margrey, K. A.; Chinn, A. J.; Laws, S. W.; Pike, R. D.; Scheerer, J. R. Org. Lett. 2012, 14, 2458-2461.

(15) DKP 12 was prepared from proline methyl ester in three steps ( 1 chromatographic separation) and $80 \%$ overall yield. See ref $8 \mathrm{~d}$.

(16) Pyrazinone structures undergo cycloaddition with molecular oxygen (without added sensitizer): (a) Machin, P. J.; Porter, A. E. A.; Sammes, P. G. J. Chem. Soc., Perkin Trans. 1 1973, 404-409. (b) Markham, J. L.; Sammes, P. G. J. Chem. Soc., Perkin Trans. 1 1979, $1885-1888$.

(17) Isomeric ratio determined by ${ }^{1} \mathrm{H}$ NMR on the unpurified reaction mixture.

(18) Acryloyl camphor sultam was prepared as described in: Thom, C.; Kocienski, P. Synthesis 1992, 1992, 582-586.

(19) (a) Oppolzer, W.; Chapuis, C.; Bernardinelli, G. Helv. Chim. Acta 1984, 67, 1397-1401. (b) Oppolzer, W. Pure Appl. Chem. 1990, $62,1241-1250$.

(20) The esterification was accomplished using reaction conditions similar to those initially reported by Evans for removal of oxazolidinone auxiliaries: Evans, D. A.; Chapman, K. T.; Bisaha, J. J. Am. Chem. Soc. 1988, 110, 1238-1256.

(21) Danishefsky, S.; Prisbylla, M. P.; Hiner, S. J. Am. Chem. Soc. 1978, 100, 2918-2920.

(22) (a) Williams, R. M.; Kwast, E. Tetrahedron Lett. 1989, 30, 451454. (b) Greshock, T. J.; Williams, R. M. Org. Lett. 2007, 9, 42554258.

(23) Hydrolysis of the lactim ether affords an intermediate ammonium methyl ester. On basification of the medium, cyclization re-establishes the [2.2.2] diazabicyclic bridge and reveals the lactam functionality.

(24) (a) Baran, P. S.; Hafensteiner, B. D.; Ambhaikar, N. B.; Guerrero, C. A.; Gallagher, J. D. J. Am. Chem. Soc. 2006, 128, 86788693. (b) Baran, P. S.; Guerrero, C. A.; Ambhaikar, N. B.; Hafensteiner, B. D. Angew. Chem., Int. Ed. 2005, 44, 606-609.

(25) (a) Clive, D. L. J.; Bo, Y.; Selvakumar, N.; McDonald, R.; Santarsiero, B. D. Tetrahedron 1999, 55, 3277-3290. (b) Calmès, M.; Escale, F.; Didierjean, C.; Cazals, G.; Martinez, J. Tetrahedron: Asymmetry 2007, 18, 2491-2496. 